\title{
A BALATON-PARTI NYARALÓK ÉPÍTÉSZETE A REKREÁCIÓ 20. SZÁZADI ÉLETFORMÁINAK TÜKRÉBEN ${ }^{1}$
}

\author{
WETTSTEIN DOMONKOS \\ PhD, egyetemi adjunktus. BME Urbanisztika Tanszék, 1111 Budapest, Múegyetem rkp. 3. K 293.
}

Tel.: (+36-1) 463-2332. E-mail: wettstein@urb.bme.hu

\begin{abstract}
A Balaton-parti nyaraló a 20. század karakteres épülettípusává vált Magyarországon, miközben a feladat kis léptékéből adódóan a szakirodalomban kevésbé került előtérbe. A tanulmány a balatoni nyaraló mint regionális szintü jelenség elemzésével arra keres választ, hogy milyen jellegzetességek mentén definiálható az épülettípus kialakulása. Az építészeti jellegzetességek átalakulásai hogyan függnek össze az üdülőhelyi életformaváltásokkal? Az elemzés forrásai a 20. század nyaralóépítészetét koncepcionális szinten elemző korabeli publikációk. A feldolgozás módszere a nyaraló jelenségét eszmetörténeti szinten, mint a regionális modellre adott eszmei válaszokat vizsgálja, a megépült példákat a koncepciók illusztrálásaként mutatja be. A tanulmány a nyaralóépítészet sajátosságait a történeti villaépítészettől elkülönítve szemléli, és rámutat az üdülőhelyi életformákból, szerkezeti megfontolásokból és formálási stratégiákból adódó jellegzetességekre. A nyaralóépítészet karakteres megoldásai a nyári hónapokra korlátozódó szezonális életformára adtak válaszokat, napjainkban azonban a tóparti életvitel egyre inkább négy évszakossá válása a lakhatási formák fokozatos átalakulását és a nyaralóépítészet tóparti jellegzetességeinek elhalványodását okozza. A tanulmány rámutat a régión belüli tényezők és a régión túli formálási irányzatok hatásaira, és hangsúlyozza, hogy bár a Balaton-parti nyaraló fogalmát a helyi adottságokhoz alkalmazkodva alakították ki, az épülettípus jellegzetességei az üdülőhelyek életvitelének általános jellemzőihez kötődött, így a régióban kialakított mintázatok más üdülöhelyeken is megjelentek, feloldva a sajátos regionális karaktereket.
\end{abstract}

Kulcsszavak: nyaraló, hétvégi ház, Balaton, regionális tervezés, modern építészet, rekreáció

„Tény az, hogy a Csonka-Magyarországon a modern szellemben készülö hétvégi ház egyelöre mint elszigetelt jelenség, itt-ott üzleti szempontból jelentkezik ugyan, de a külföldi hétvégi házak nagyarányú elterjedésével összehasonlitva elmondhatom, hogy bizony csak gyermekcipőben jár. Mert ami eddig megépült-egy-két típus kivételével - szomorú és gyászos hétvégi házak azok. Szomorú és felháboritó látvány az, hogy a nagyjövöjü Dunánk mindkét partját [sic], de különösen a Balatonunk körül épült »weekend-házak « örve alatt a kor és felfokozott igényekkel [sic] egyáltalán nem számító elavult és drága viskókat tákolnak össze egyes hozzá nem értők, akiknek fogalmuk sincs a korszerü hétvégi ház megalkotásáról."2

${ }^{1}$ Az MTA Építészettörténeti, Építészetelméleti és Mủemléki Állandó Bizottság és a Településtudományi Állandó Bizottság által szervezett, ,,bauhaus 2019” címü konferencián, Budapesten 2019. június 12-én elhangzott előadás szerkesztett és bővített változata.

${ }^{2}$ Molnár 1931. 297-298. 

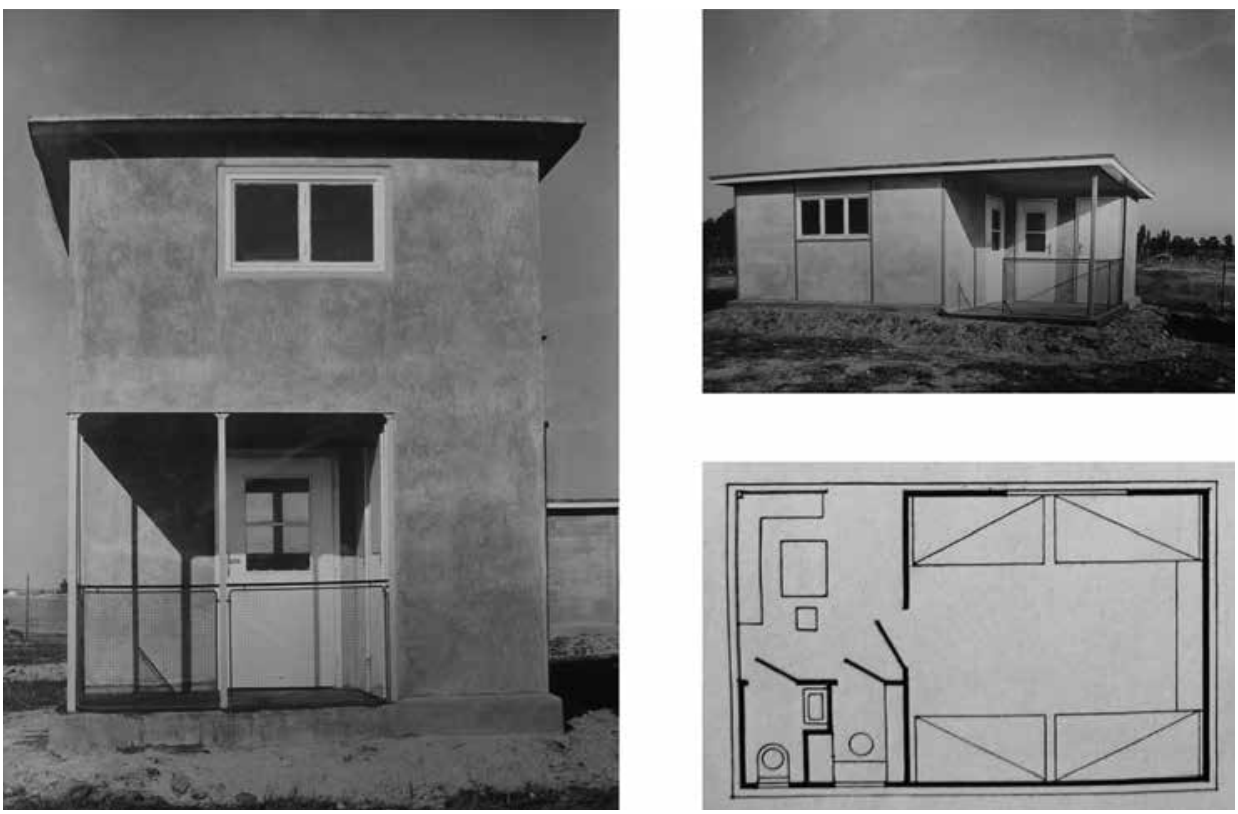

1. ábra. Molnár József vasvázas balatoni nyaralóinak képei.

Forrás: Molnár 1931. 297-298.

Molnár József a Tér és Forma 1931-es számában fogalmazta meg kritikáját a korabeli nyaralóépületekkel szemben. Kritikája korszakoktól függetlenül visszhangzik a Balaton-part nyaralótelepein, az általa felvázolt fogalmi probléma ma is aktuális. Molnár József a CIAM magyar csoportjában is részt vett, a kritikához kapcsolódóan saját korszerü vasvázas nyaraló mintaterveit is publikálta (1.ábra). Az elkészült prototípusokról készített felvételek a CIAM titkáraként tevékenykedő Sigfried Giedion archívumában is fellelhetőek. Az épület tisztán mutatja a modern hétvégi ház szerkezeti és térhasználati formálásában rejlő lehetőségeket. Ezek az elvek, melyek elsősorban a szezonális életformához kötődtek, a 20. század nyaralóépítészetét erősen áthatották és korszakoktól függetlenül a tópart egyszerü, fesztelen hétvégi házának ideáját alakították ki a tematikus publikációkban és a közbeszédben egyaránt.

\section{A BALATON-PARTI NYARALÓ MINT REGIONÁLIS SZINTÚ MODELL}

A „Balaton-parti nyaraló” fogalommá vált nemcsak az építészeti, de a tágabb társadalmi közbeszédben is, miközben a témakör egységessége, a fogalom építészeti definíciója egyáltalán nem egyértelmü. Érezzük, hogy a tóparti építészetnek mint- 
ha sajátos karaktere lenne, amit egyfajta Balaton-parti identitással is gyakran összekapcsolunk, ugyanakkor a tópart építészete épp a nyaralóépítészet heterogenitásából fakadó zavaros településképpel küzd kezdetektől fogva. A nyaraló fogalma egyre gyakrabban tünik fel a társadalomtudományi vagy történeti kutatásokban is, az építészeti értékelés, formálás tekintetében azonban sokszor problémás fogalomtársításokkal. Épp ezért szükségesnek tűnik a témakör építészet szempontú eszmetörténeti vizsgálata is, ami hozzájárulhat az interdiszciplináris kutatások megalapozásához.

A nyaraló fogalmának és koncepciójának tisztázását a tervezői szakmagyakorlás is megkívánja. A tóparti életforma az utóbbi évtizedekben egyre inkább átalakul, a szezonális használat háttérbe szorul, ami a nyaralók jellegzetességeit is átalakítja. Ma már a családi házakkal egyenértékủ szerkezeti és térhasználati igényekkel építkeznek, ennek révén a hétvégi ház korábbi, könnyed ideája egyre inkább eltünik a tópartról. Az egész éves használatból adódóan a „nyaraló” fogalom is értelmét veszti, az új villaépítészet számára azonban szükséges az épülettípus történeti előzményeinek felvázolása, a kontinuitást adó tóparti jellegzetességek megfogalmazása. A 20. századi nyaraló eszme eltünését erősíti, hogy a kezdeti ideát tükröző alkotások épp most érnek abba az életciklusba, ahol a tulajdonosoknak dönteniük kell az épületek felújításáról. A könnyed szerkezetủ nyaralók azonban sok esetben nem alkalmasak a gazdaságos megújításra, ugyanis a szezonális épületek hőszigetelésével, térstruktúrájuk bővítésével épp azokat a jellegzetességeiket vesztik el, ami könnyed karakterüket kifejezte.

A tanulmány a szerző doktori disszertációjához is kapcsolódik, ugyanakkor egy olyan résztémát dolgoz tovább, amelynek koncepcionális kifejtésére a doktori értekezésben nem nyílt lehetőség. ${ }^{3}$ A disszertáció a Balaton-part építéstörténetében megjelenő regionális szintű stratégiaalkotás folyamatát vizsgálta, a dolgozat több léptékszintet átfogó szerkesztésekor azonban nem nyílt lehetőség a nyaralóépítészet koncepcionális kérdéseinek és összefüggéseinek kirajzolására. Jelen tanulmány épp ezt a hiányt igyekszik pótolni, célja a nyaraló fogalmának eszmetörténeti vizsgálata a Balaton-parti nyaralóépítészethez kapcsolódó tematikus publikációk és tervezéstörténeti dokumentumok tükrében. ${ }^{4} \mathrm{Az}$ elemzés arra keresi a választ, hogy a történeti koncepciók alapján hogyan fogalmazhatóak meg a Balaton-parti nyaraló eszme általános jellegzetességei? Az egyes korszakok közt milyen értéktényezőkben mutatható ki kontinuitás? Szükséges azt is kritikai szempontból megvizsgálni, vajon mennyiben kötődik ez a karakter a Balaton régió sajátosságaihoz és milyen külső hatások és építészeti tendenciák érvényesültek? A tanulmány modellszerüen vizsgálja a nyaraló fogalmát, amely nemcsak a Balaton régió eseti jellegzetességeire, de az épülettípus hazai és nemzetközi formálási tendenciáira is példát mutat.

\footnotetext{
${ }^{3}$ A doktori disszertáció a Balaton-part 1929-1979 közötti tervezéstörténeti időszakában vizsgálja a rekreációs célú építészet problémáira kidolgozott regionális szintű stratégiák eszköztárát. Wettstein 2018a.

${ }^{4}$ A szerző korábbi, csak az egyes részkorszakokra fókuszáló publikációit a Balaton-parti nyaraló építészetéröl lásd: Wettstein 2012; Wettstein 2017; Wettstein 2018b. Jelen tanulmány célja a korszakok közötti összefüggések, a nyaralóépítészet általános jellemzőinek modellszerü elemzése.
} 
Az elemzés tárgya tehát a nyaraló fogalma, amit elsősorban a történeti publikációk, regionális szintü dokumentációk tükrében vizsgálunk. Erre az eszmetörténeti horizontra azért is van szükség, mert a nyaralóépítészetnek mint jelenségnek a lehatárolása rendkívül problémás. Az épülettípus erősen kapcsolódik a tömegtársadalom és a tömegturizmus kialakulásának időszakához, a nyaralóépítészet problémája épp a tömeges jellegéből fakadt minden korszakban. Számosságából adódóan a témakör vizsgálata is sajátos eszközöket kíván. Épp ezért szorítkozunk elsősorban az eszméket reprezentáló dokumentumokra, melyeket a jellegzetes megépült példák illusztrálnak. Elsősorban arra kell választ találnunk, hogyan határolható le a jelenség? Az időbeli lehatárolás kezdőpontját meg tudjuk adni, éles lezárást azonban - bár korábban már említettük a fogalom elhalványodását - a jelenbe kifutó tendenciák miatt nem szükséges megadnunk. Bár a tóparti villaépítészet előzményei a római korra is visszanyúlnak, közvetlen elözményei a reformkorra tehetőek, a nyaraló és hétvégi ház karakteres formájának megjelenése az első világháborút lezáró trianoni döntést követő időszakhoz köthető. A térbeli lehatárolásnál a Balaton-parti üdülőterületekre vonatkozó koncepciókat és példákat vizsgáljuk, ugyanakkor fontos utalni arra, hogy a Balaton-parti nyaraló fogalomhoz hasonló jelenségek a kor más üdülöterületein is megjelentek. Az ezek közötti kapcsolatokra, hatásmechanizmusokra a tanulmány több pontján utalunk. A lehatárolás másik eszköze a típus elkülönítése a történeti és kortárs villaépítészettől. Ez elsősorban a szezonális életformához kapcsolódó térhasználattal és szerkezeti megfontolásokkal lehetséges. Az épülettípus karakteréhez jelentősen hozzájárul, hogy elkülönül az összetett térstruktúrával és az egész éves tartózkodást lehetővé tevő szerkezeti kialakítással bíró villaépítészettől. Ugyanúgy elkülönül a népi építészethez kapcsolódó üdülési célú építkezésektől, de emellett szükséges a zártkerti építéstől és a saját kezüleg barkácsolt hajlékoktól is elkülöníteni mind a szerkezeti, mind a térhasználati jellegzetességek miatt. A villaépítészet és a saját kezü barkácsolás kijelöli a témakör kontúrját az üdülőterületi magánépítkezések tipológiáján belül. Ebben a kontextusban is egy eltünőben lévő müfaj, épülettípus elemző bemutatása a tanulmány célja.

\section{A VILLAÉPÍTÉSZET MINT ELŐZMÉNY - TERVEZÉSTÖRTÉNETI PROBLÉMA}

A nyaralóépítészet előképei és mintái kezdettől fogva problémát jelentettek az építészek számára. A korábban már kialakult villaépítészet elsősorban a tehetősebb társadalmi rétegek igényeire adott válaszokat. A Balaton-parti villaépítészet előzményei a római korra nyúlnak vissza. A tóparton feltárt villákat azonban nem üdülés céljából, hanem állandó lakóhelyként építették, ami a vidék és városiasodás kiegyensúlyozott viszonyát mutatja a római provinciákban. Egyes tanulmányok szerint a római kori provinciák korai urbanizált tájakként is értelmezhetőek, elsősorban az öket átszövő fejlett úthálózatok révén. ${ }^{5}$ Mindez a jelenkori táji urbanizációs tenden-

${ }^{5}$ Firnigl 2012. 
ciák tükrében is érdekes előzmény. A római kori villákat csak a 4. századtól kezdve kezdték el rekreációs célokra használni. A Birodalom meggyengült, a tulajdonosok inkább a biztonságosabb városokba húzódtak, és csak nyaranta tértek vissza a feltöltődést adó táji környezetbe. A római uralmat követően hosszú évszázadokig nem használták üdülés céljára a tájat, csak a 18. század végén kezdtek el ismét villákat építeni, elsősorban az északi parti szőlőhegyeken. A házakat a szüreti időszakokban használták elsősorban. Az első jelentősebb villákat Füreden építették a reformkor idején, de ennek az üdülésnek sem a Balaton-part volt a bázisa, hanem az északi parton, több helyen is feltörö gyógyvíz. A tóparti villatelepek fejlődésének a vasút kiépítése adott lendületet. Ebben a képben a vasút a tóparti modernitás szimbólumaként jelenik meg, ami összekötötte a régiót a nagyvárossal, és eközben az infrastruktúra kiépítése révén jelentős tájformáló hatással is bírt. A Déli Vasutat 1861-ben nyitották meg, de hamar a vízszintingadozás áldozatává vált a pályatest. Épp ezért döntöttek a siófoki zsilip megépítéséről és a Balaton vízszintjének többméteres sülylyesztéséről, amely révén a déli parton egy jelentős, úgynevezett „,apadási öv” alakult ki. Ezen a frissen nyert területen, történelmi előzmények nélkül, az ősközségektől függetlenül alakultak ki az első villatelepek. Ezeknek a korai fürdőtelepeknek természetközeli jellegük volt, a villákat az akkor még sok esetben érintetlen vagy frissen parcellázott tóparti környezetbe illesztették. A turizmus és a rekreáció kezdettől fogva erős antiurbánus indíttatással bírt. ${ }^{6}$ A városból nyaranta kivonuló polgárok egy ellentett világot kerestek, ahol a természet és a kisközösségi lét rekreációt nyújtó közelségét keresték. Ezzel a vágyakozással együtt azonban a komfort és a modernizáció korabeli vívmányai iránti igény is hamar megjelent.

Még ma is számos korabeli villa áll Siófokon, Földváron, Balatonszemesen, Bogláron, Bélatelepen ebből a korszakból ${ }^{7}$ (2. ábra). Ezeknek a villáknak általános jellegzetességük, hogy mind funkcionálisan, mind szerkezetileg a városi villákkal egyezően építették fel őket. ${ }^{8}$ A falak vastagsága, a nyílászárók kialakítása az egész éves tartózkodást is lehetővé tette, ugyanakkor jellemzően csak két hónapig használták őket. A térbeli kialakításukban a városi életvitelnél megszokott igényeket tartották szem elött. A 250-300 négyzetméter alapterületü épületekben vendégszobát és cselédszobát is kialakítottak, a nappali teréhez tágas hálószobák kapcsolódtak. Az üdülőhelyi életvitel jellegzetes térformája a veranda volt. Ez a fedett nyitott tér a nappali szoba teréhez kapcsolódott és azzal közel egyező arányú, négyzetes alapterületű volt. A villák építészeti kialakítása a városi polgárság önreprezentációját szolgálta. Elsősorban a történeti építészet hatásai jelennek meg az épületeken, de jellemzően a formákat csak elnagyoltan vették át, sokszor naiv módon alkalmazták. Az épületek formáját nagyban alakította a korabeli hegyvidéki üdülőhelyi építészet. Az alpesi utazások emlékét megidézve a faszerkezetű építészet terjedt el, ami játé-

${ }^{6}$ A 20. század eleji városi építészeti tendenciák közé sorolja Meggyesi Tamás az antiurbánus törekvéseket. Meggyesi 2005.

${ }^{7}$ A korszak fürdőtelepeinek elemzését lásd: Bősze 1989. 211-252.

${ }^{8}$ Kotsis 1934. 102-106. 

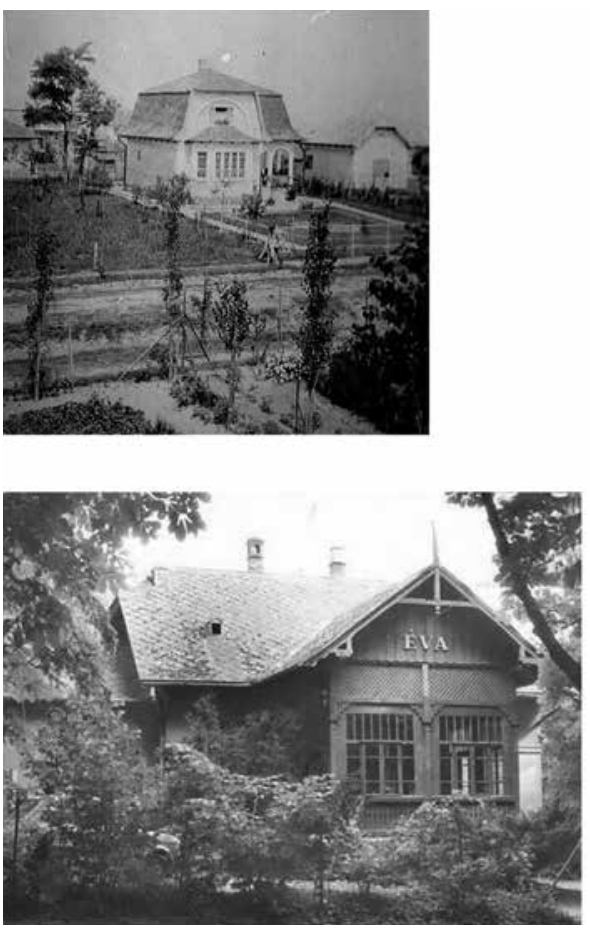
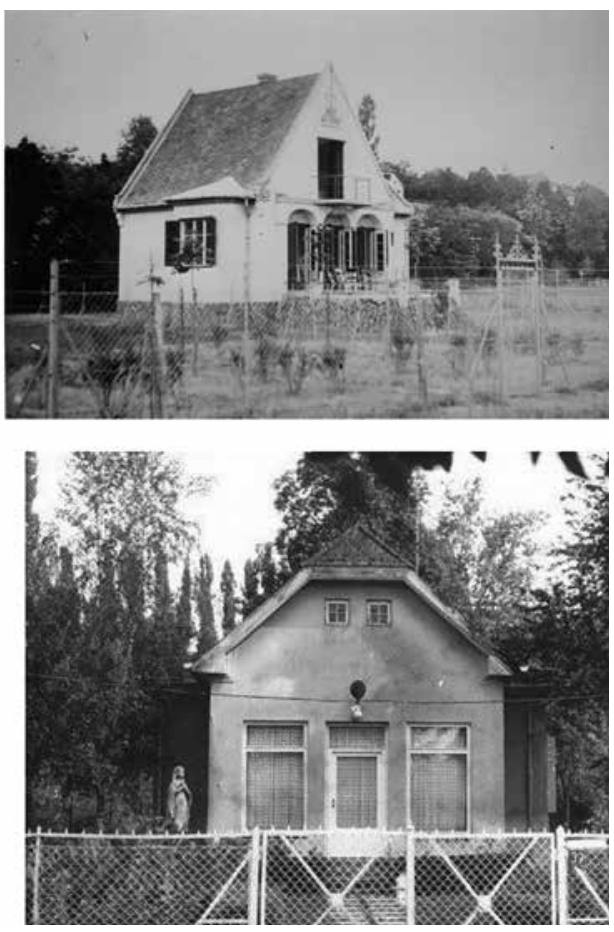

2. ábra. Villaépítészet Balatonszemesen az 1900-as évek elejéről. A szerző felvételei

kosságával és könnyedségével a rekreáció romantikus atmoszféráját fejezte ki. A faépítészet gazdag részletképzésében rejlő lehetőségekre láthatunk példákat a bélatelepi villasoron. A téglafalazatú épületeket faszerkezetü verandával egészítették ki és meredek hajlásszögű tetősíkokkal fedték. A karakterjegyek révén az úgynevezett „svájci villaként” honosodtak meg nemcsak a Balaton-parton, hanem más üdülőhelyeken vagy épp a főváros környékén, a budai hegyvidéken. Ezt a sajátos villaépítészetet és a városias stílusok hátrahagyását az üdülőhelyek antiurbánus karaktere is inspirálta. Az első villatelepeket 500-600 négyszögöles telekosztással parcellázták, az utak mellett fasorokat telepítettek, a központokban parkot, valamint a korabeli sport- és klubélet építményeit helyezték el. Az egyes telkeken a villák körül kertépítészetileg is rendezett, tágas kerteteket alakítottak ki, ahova további kiegészítő építményeket is elhelyeztek.

Az első világháborút követően az ország elvesztette történelmi üdülőhelyeit, a bezárt országban felértékelődött a Balaton-parti nyaralás lehetősége. A középosztály egyre szélesebb rétegei számára vált elérhetővé a régió, azonban az új értelmiségi vagy tisztviselő réteg kevesebb anyagi erőforrásból tudott építkezni, miközben a modernizáció révén egy új életformát is hozott a tópartra. Ez nagyban hozzájárult a korábbi villaépítészet átalakulásához, és egy új, egyszerübb épülettípus megjelené- 
séhez. A villaépítészet azonban nem adhatott követhető mintákat az első világháborút követő egyszerűbb és gazdaságosabban megépíthető térformákat kereső nyaralóépítészet számára. Az új nyaralótelepeket már jóval szükösebb, 300 négyszögöles parcellákon osztották ki, az úthálózat és közterületek kialakítására kevesebb figyelmet fordítottak. Az új telekosztásokban a parcellázók profitorientált gondolkodása érvényesült, ami sok visszássághoz vezetett. Az épületek megépítése és fenntartása, valamint az összetett térsorok használata nem volt alkalmas a modernizálódó üdülőhelyi életforma számára. Épp ezért a nyaralóépítészetet a modernitás vagy épp a modern építészet új funkciójának, prototípusának szokták tekinteni, bár formálásában sem a nemzetközi, sem a magyar tendenciákban nem kötődik tisztán a modern építészethez. A két háború közötti időszakban egyre több publikáció született a nyaralóépítészetről, sok esetben kifejezetten a Balaton-partra fókuszálva, újra és újra feltéve a kérdést, mit is jelent a nyaralóépítészet? Az elvek megfogalmazásában egyetértettek abban, hogy történeti minták nem állnak rendelkezésre, és ezeket az elveket a hatvanas-hetvenes években tudatosan vették át a nyaralótípust újrafogalmazó tematikus kiadványok.

\section{A SZEZONÁLIS ÉLET FORMÁI - A NYARALÓK FUNKCIONÁLIS KIALAKÍTÁSA}

A nyaralót a szezonális életforma könnyed életvitelére alakították ki. Az első világháborút követően fokozatosan átalakult a nyaralás felfogása, az új szerényebb anyagi forrásokkal rendelkező építtető réteg sem az építési költségek, sem az életvitel szempontjából nem kereste a villaépítészet korábbi összetett és nehézkes formáit. ${ }^{9}$ Ahogy Kotsis Iván a nyaraló ideáljának megfogalmazásában leírta, a villákhoz képest jelentős eltérés, hogy kerülték a városias vagy nagypolgári életvitelből származó helyiségeket, így a reprezentatív nappalikat, a vendég- és cselédszobákat, mert a villák jelentős 40 000-50 000 pengős építési költségét a középosztály nem tudta vállalni. ${ }^{10} \mathrm{Az}$ alacsony építési költségeket is szem előtt tartva, a nyaralók jellemzően 50-100 négyzetméter alapterülettel épültek, de sok esetben csak a létszükséglet minimumára összpontosítva 25-30 négyzetméteres nyaralókat építettek. ${ }^{11}$ A korabeli publikációkban a hálószobák helyett hálókamrákat javasoltak, bár ez a tértípus kevésbé terjedt el annyira, mint azt a kezdeti tanulmányokban előre jósolták. Egyre nagyobb szerepet kapott viszont a fedett, nyitott terű veranda, ami már jóval egyszerübb formában jelent meg. A központi térhez kapcsolódott, és tekintettel az épület kis alapterületére, a napközbeni tevékenységek még rosszabb időjárás idején is az átme-

\footnotetext{
${ }^{9}$ A két világháború közötti időszak részletes elemzését lásd: Wettstein 2017. A villaépítészet átalakulásához lásd az alábbi esettanulmányt: Wettstein 2012.

${ }^{10} \mathrm{~A}$ villaépítészet és a nyaraló felfogása közötti szemléletbeli különbség Kotsis Iván korabeli tanulmányában is megjelenik. Kotsis 1934. 102-106.

${ }^{11}$ A két háború közti időszakban megjelenő nyaralóépítészeti tanulmányokat lásd: Komor 1931. 41-66; Kotsis 1934. 102-106; Kotsis 1931. 8-10; Möller 1944. 200; Nemes 1935. 69-78; Széll 1934. 112-115.
} 
neti térben zajlottak, ezzel a kert természeti környezetével egy szorosabb szimbiózis alakulhatott ki. A nyaralóépületek sokszor kényszer szülte egyszerübb, kertbe ágyazott kialakítása az a motívum, ami a rekreáció antiurbánus, természetközeli karakteréhez vezette vissza a nyaralókat (3. ábra).

Ezt a felszabadult építészeti magatartásformát erősítették azok a tendenciák, amelyek a 20. század második felének nyaralóépítészetét alakították. ${ }^{12}$ A második világháborút követő társadalompolitikai változások és a tópart modernizációja révén egyre szélesebb társadalmi rétegek számára vált elérhetővé a Balaton-part. ${ }^{13}$ A politika a forradalmat követö konszolidációs program, majd a hatvanas, hetvenes évek életszínvonal-növelését elösegítő intézkedések jegyében a belföldi lakosság számára a hétvégi ház építésének lehetőségével kívánta megadni a magántulajdon és a szabadság illúzióját. ${ }^{14}$ Egyre több és egyre kisebb telket parcelláztak a tóparton. Míg a századfordulón 5-600 négyszögöles, a két háború között pedig 300 négyszögöles telket osztottak ki, az 1960-as években sokszor már csak ezek felét, a minimálisan elöírt 158 négyszögöles telekosztást alakítottak ki, ezzel szükségszerüen besürítve a telepeket. Nem véletlenül fogalmazott úgy Farkas Tibor: „az üdülöterület nem vadon, hanem sürün települt táborhely”. ${ }^{15}$ A kicsi telkeken valóban sokszor már csak olyan egyszerüségü nyaralókat építettek fel, amelyek nem sokban különböztek egyegy sátor vagy campingépület alapterületétől. Mindezt a korszakban megjelenő típustervek is erősítették. A korabeli publikációkban kiemelték, hogy az üdülni vágyó számára a hétvégi ház csak hajlék, menedék, hisz ideje nagy részét a szabadban

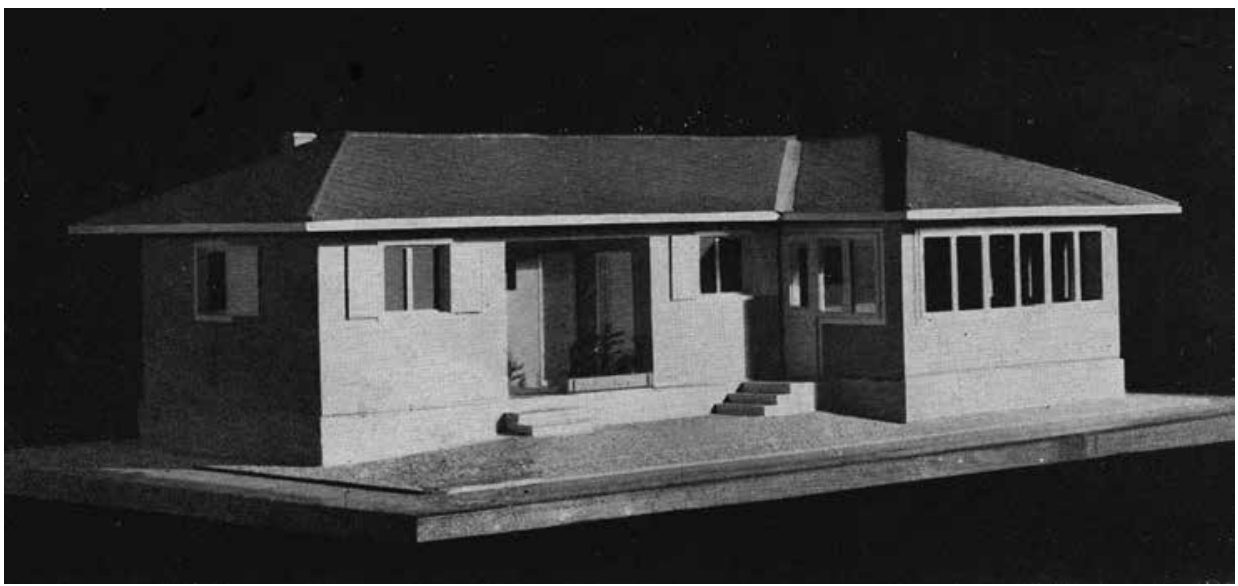

3. ábra. Kotsis Iván nyaralómodellje. Forrás: Kotsis 1946

${ }^{12}$ A 20. század második fele nyaralóépítészetének korabeli publikációit lásd: Callmeyer 1960. 23-29; nn 1962.

${ }^{13}$ A hatvanas és hetvenes évek magánépítkezésiről részletesebb elemzést lásd: Wettstein 2018a; Wettstein 2018 b.

${ }^{14}$ Németh 2016. 137-156.

${ }^{15}$ Bérczes et al. 1960. 15-26. 
tölti. ${ }^{16} \mathrm{Ez}$ a tendencia egészen közel vitte a nyaralás felfogását a nomád életvitelhez. Az urbánus világ hátrahagyásával az ember a rekreációban a természetközeli létformához szeretne közel kerülni. A városi építészet adta komfortot nemcsak az anyagi erőforrásainak szükössége, de a fesztelen életvitele miatt is hátrahagyja. Ahogy Ormos Imre, a korszak jelentős tájépítésze és az első Balatoni Regionális Terv szakértője a „szabad táj” címü esszéjében megfogalmazta, a táj közvetlen megtapasztalása, a természet elemi tényezőire történő ráhagyatkozás az, ami a városi ember számára a feltöltődést megadja. ${ }^{17}$ Mindezt az egyszerü térformáival, a természeti környezettel alkotott közvetlen térkapcsolataival ezeknek a nyaralóknak az építészete is kifejezi.

A nyaralás életvitele a 20. század során folyamatosan formálódott. Egyre szélesebb társadalmi réteg építkezett, egyre egyszerübb és kisebb léptékben. A Balatonpart kezdett besürüsödni, ezért elkezdtek alternatív nyaralási formákat kikísérletezni. Megjelentek a sorházas nyaralótelepek és a többszintes társasüdülők, a mai apartmanházak elödjei. ${ }^{18}$ Ez utóbbiban a városi lakhatási formákhoz hasonlatosan a kerttől elemelt lakásokban nyaralhattak. Ezzel egyidőben megindult a korábban védett zöldterületek beépítése is. Bár az első regionális tervben Farkas Tiborék szigorúan védték a külterületek parcellázását, 1968 után a Főépítészség megszüntetésével egy időben a szabályozást fellazították. ${ }^{19}$ Egyre több, korábban védett zöldterületet vontak belterületbe és osztottak ki, valamint megindult a termelőszövetkezetek részéről a zártkerti ingatlanok értékesítése. A történelmi szőlőterületeket és gyümölcsöskerteket adták magántulajdonba, a parcellákon az új tulajdonosok azonban nem mezőgazdasági tevékenységet folytattak, hanem a szabályozást kijátszva építkeztek. A tájrombolásnak nemcsak esztétikai, de ökológiai következményei is voltak. A művelés elmaradásával megindult a talajerózió. Épp ezért Laposa József tájépítész a „tevékeny üdülés" koncepcióját dolgozta ki, ahol a rekreáció és a kertmüvelés szorosan összekapcsolódik, ezzel segítve a táj védelmét. Az aktív pihenést szorgalmazó elképzelése visszhangtalan maradt. ${ }^{20}$

Az életformaváltásokat a turisztikai érdeklödés átalakulása is befolyásolta. A hetvenes évek második felétől a besürüsödő tópart helyett a vernakuláris kultúrában gazdag Balaton-felvidék felé fordult az érdeklődés. A népi építészet iránti fogékonyság kezdettől fogva jelen volt a turisztikában, így a Balaton-parti turizmus koncepciókban is. A 20. század utolsó harmadában ugyanakkor már a tóparttól távolabb eső, csendesebb helyszíneket is egyre többen választották a nyaralás helyszínéül. Ebben a helyzetben már nem a tópart könnyed nyaralóépítészetét alkalmazták, hanem a vernakuláris életforma közvetlen-közvetett megtapasztalását, a népi építészeti térformák újraértelmezését, még ha ez sok esetben ambivalens megoldásokat eredményezett is.

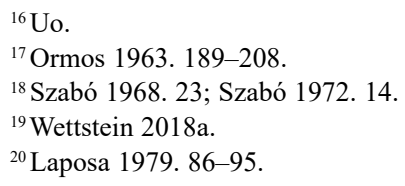


A rendszerváltást követően a tóparti életvitel is fokozatosan átalakult. A társadalom életszínvonalának emelkedésével már egyre kevésbé vált vonzóvá a szezonális nyaraló. A mobilitás fejlödésével ma már az év minden szakában könnyen elérhető a tópart, a különböző életformák egymás mellett jelennek meg. Egyre több korábbi üdülő választja új állandó lakhelyül a régiót, az üdülőterületeken is megjelentek az állandó életvitelt biztosító családi házak. A korábban élesen meghúzott üdülöhelyi határ elmosódik. A korszak regionális stratégiáiban a Balaton-part víziója már nem üdülőterület vagy nyaralótelep, hanem egy egyre inkább agglomerálódó „kertváros”. Egyre nagyobb számban épülnek a korábban már említett társasüdülök mai változatai, az új léptéket képviselő apartmanházak, karakteresen átrajzolva a tóparti nyaralótelepek összképét. Az új építésü nyaralók visszatérnek a századforduló villáinak összetett térigényéhez, határoló szerkezeteik hőszigeteléssel, belső tereik fütésrendszerrel épülnek. A szerkezetek vaskosabb formai megjelenése a nyaraló könnyedségében rejlő idea feladásához vezet. A szezonális életforma háttérbe szorulásával a nyaraló fogalma, korábbi természetközeli, fesztelen életvitelre épülő értelmezése is elhalványodik. A 20. századot jellemző életforma-változások tendenciái a nyaraló fogalom számára is sajátos értelmezési keretet rajzolnak ki.

\section{ÉLETMÓD ÉS ÉPÍTÉSMÓD - ALKALMAZKODÁS A SZERKEZETVÁLASZTÁSBAN}

A szerkezeti kialakítást a szezonális jelleg, a gazdaságos kialakítás és a vidéken rendelkezésre álló technológia korlátossága egyaránt befolyásolta. A technológiai korlátok különösen a kezdetekkor, a két világháború közötti időszakban voltak meghatározóak. A korabeli publikációkban inkább az alacsonyhajlású tetőket propagálták, mivel a lapostetőket a vidéki kivitelezők még nem tudták kellő szakszerüséggel megoldani. ${ }^{21}$ Mindez hatással volt a modern építészeti formálás visszafogottabb elterjedésére is a tóparton. A nyaralóépítészetet ezzel együtt is a szerkezeti sokféleség jellemezte az egész 20. század során. Kezdettől fogva jelen voltak a hagyományos falas és vázas technológiák, az 1960-as évektől pedig az előregyártott elemek és karosszériaszerü egységek is megjelentek, miközben az építészet perifériáján különböző mértékü saját kezü építés is folyamatosan problémákat okozott. A szerkezetválasztás széles lehetőségei a formálás és az esztétikai értelmezések sokféleségét eredményezte, ami a településkép zavarosságát okozta az üdülőhelyeken. Ahogy Polónyi visszaemlékezésében megfogalmazta: „, a spontán népi épitészet épület és településformáját igen határozottan determinálták a klimatikus adottságok, a rendelkezésre álló építöanyagok és a helyi épitéstechnológia. Ma már azonban az építöanyagok tág választéka és a gépészeti megoldások miatt nincsenek korlátok... "22

\footnotetext{
${ }^{21}$ Nemes 1934; Nemes 1935; Széll 1934; Schulek 1934. 101.

${ }^{22}$ Polónyi 2004.
} 
Tekintsük át mindazokat a helyi tényezőket, amelyeket rendre megemlítenek a korabeli publikációk. ${ }^{23} \mathrm{~A}$ klimatikus adottságokhoz való alkalmazkodás is fontos szempontként jelent meg kezdettől fogva. Legfontosabbnak az északnyugati uralkodó szélirányt emelték ki, ami gyakran viharossá fokozódik. Emellett a magas talajvízszintet hangsúlyozták, ami a partközeli területeken megakadályozta az épületek alápincézését. A rendelkezésre álló helyi építőanyagokat ugyanakkor kezdettől fogva javasolták, egyfelől a gazdaságosság, másfelöl a táji környezethez való alkalmazkodás szempontjából. A természetes kőfalazatok, a faszerkezetek, vagy akár a nádfedések korszakoktól függetlenül vissza-visszatéröo ${ }^{24}$ motívumaivá váltak a természet közelségét kereső nyaralóépítészetnek. A költséges fuvarozás miatt is javasolták az olyan helyi anyagokat, mint az északi parton müködő téglagyárak termékei, a vöröshomokkő vagy a badacsonyi bazalt. A bazalt jó hőszigetelő képessége miatt könnyübetonba rakva vagy falazáshoz is kiváló. A vöröshomokkövet az északi parthoz közeli kőbányákban termelték ki. A betonozási munkákhoz a hajmáskéri és a füredi murvát ajánlották, ugyanakkor a Balaton-partról kikotort homokkavics rossz eredményeket adott a cementtapadás vizsgálatánál a szemcséket bevonó iszapréteg miatt, ezért nem ajánlották. A bekezdésben felsorolt táji-klimatikus adottságok, rendelkezésre álló építőanyagok nagyban hozzájárultak a Balaton-parti nyaraló sajátos karakterének kialakításához.

A legtöbb nyaraló hagyományos építésmóddal, azon belül is falazott technológiával készült. Általánosságban téglafalazattal, de gyakorta megjelennek a vakolat nélkül karakteres megjelenést adó helyi kőfalazatok is. Az almádi vöröshomokkő kedvelt anyag volt nem csak a kitermelés környezetében fekvő településeken, lábazati anyagként az egész tóparton elterjedt. A vulkanikus köveket is gyakorta használták, például Sajkodon az üdülötelep karakterét erőteljesen meghatározza a helyi kőfalazatú épületek egységes látványa. Bár a gazdaságossági szempontok miatt az épületeket vékonyabb falakkal építették meg, a harmincas években a nyári túlmelegedés elkerülésére javasolták a vastagabb vályogfalakat is. Az alapozás tekintetében a kis teherből adódóan kezdetben megszakított alapokat építettek, a kimaradó szakaszokat az alaptestek közt átboltozva. A déli parton mindig is problémát jelentett a magas talajvíz, ezért jellemzően itt nem építettek pincéket, helyette a padló alatti légszigetelést javasolták, ami az átszellőztetés révén a falak és a földfeltöltés nedvességét egy kürtőn keresztül elszállította. A 8-10 hónapig használaton kívüli ház esetében problémát jelentett a szellözetlenség és a nedvesség, ezért az üreges deszkafalak nem terjedtek el. A tetőformáknál az egyszerübb és alacsonyabb hajlásszögü tetőidomokat helyezték előtérbe, mert azokban a viharok nem tudtak kárt tenni (4. ábra). A lapos terasztetőket előszeretettel építették a kilátás érdekében, de ezek a téli fagyok idején nagyon sérülékenynek bizonyultak. A homlokzatképzésben meghatározó szerep jutott az árnyékolóknak, zsalugátereknek. Hőszigetelés hiányában a falburkolás nél-

${ }^{23}$ Antal 1931; Nemes 1935; Széll 1934. A második világháborút követően már nem foglalkoztak ilyen részletességgel a helyben rendelkezésre álló anyagokkal, hagyományos építésmódokkal.

${ }^{24}$ Wettstein 2017. 

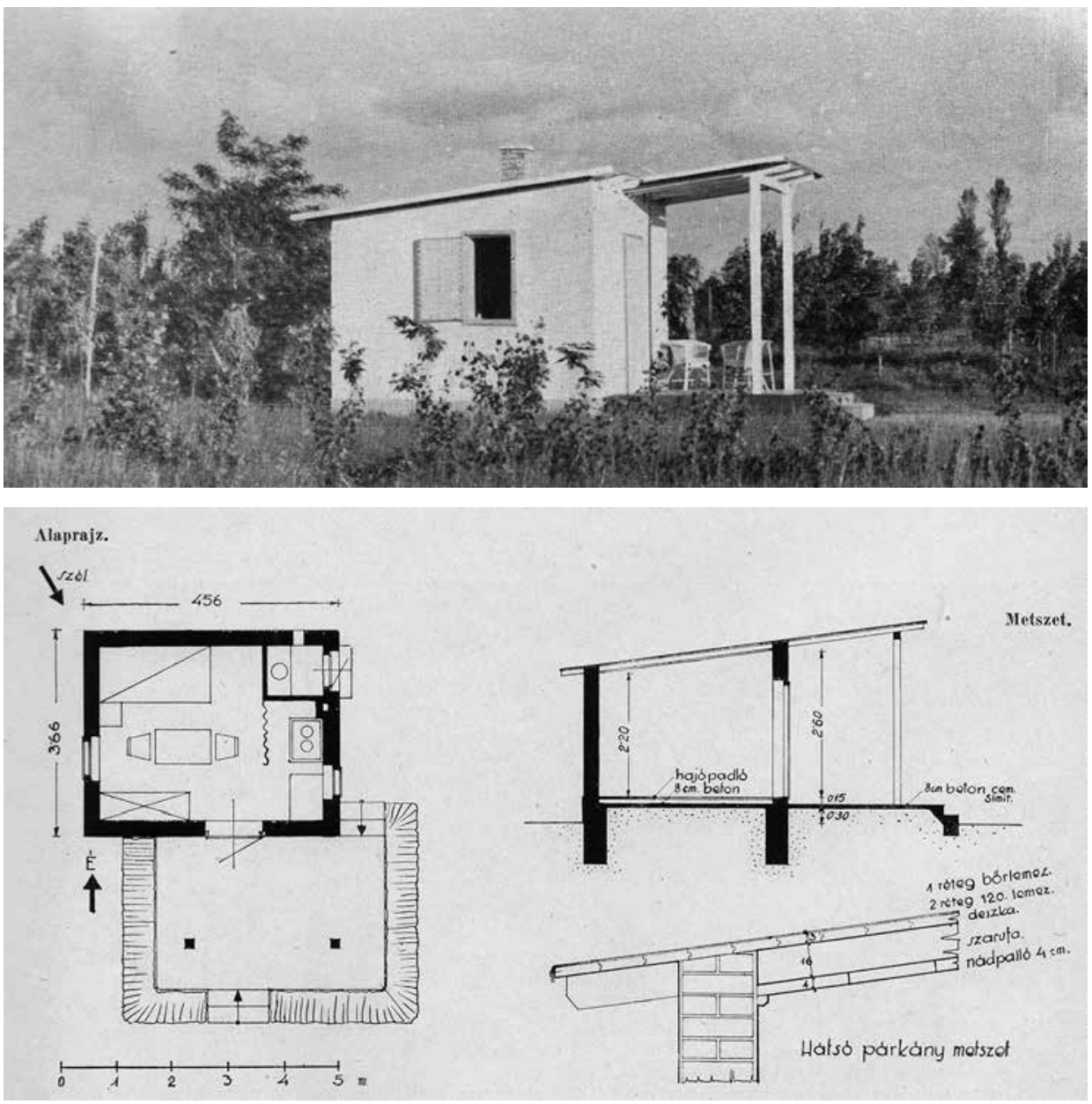

4. ábra. Kotsis Iván: Hétvégi ház Balatonújhelyen. Forrás: Kotsis 1946

küli, egyszerübb tokszerkezetủ nyílászárók terjedtek el. Ezekre a nyaralókra korszakoktól függetlenül számos példát találunk. A Tér és Forma tematikus lapszámokban mutatta be a mintaterveket és a kiválogatott alkotásokat. ${ }^{25}$

Vázas építésmódra kevés példát találunk, elsősorban a nyári felmelegedés miatt nem terjedtek el a könnyüszerkezetes nyaralók. Vasvázas épületre a bevezetőben említett Molnár József hétvégi háza lehet példa, de a későbbiekben elsősorban a favázakat alkalmazták. A faszerkezetủ nyaraló játékos formáját mutatja Kiss Tibor mintatervként közzétett vázlata. ${ }^{26}$ Később ez az egyre inkább leredukálódó archetipi-

${ }^{25}$ Antal 1931; Fabiny 1935.

${ }^{26}$ Antal 1931. 


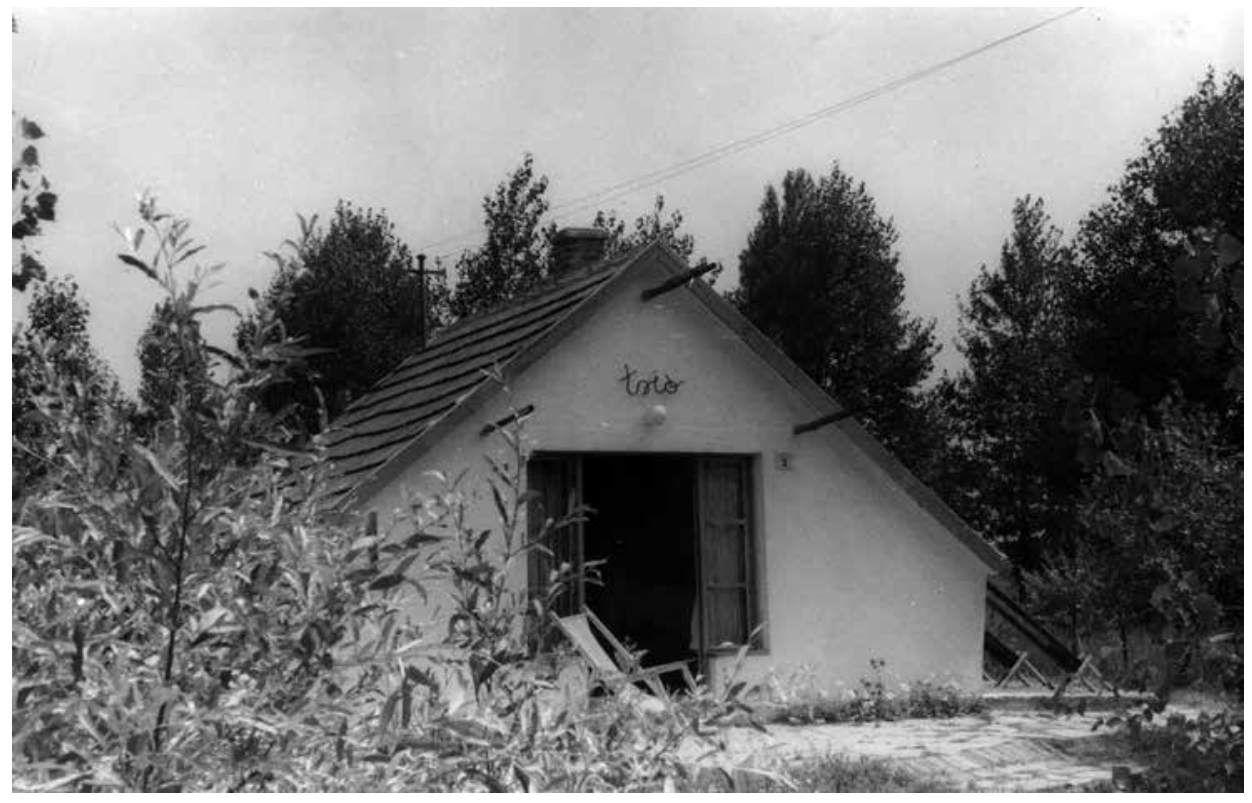

5. ábra. Farkas Tibor: Trió nyaralóterv. Forrás: Farkas Tibor archívuma
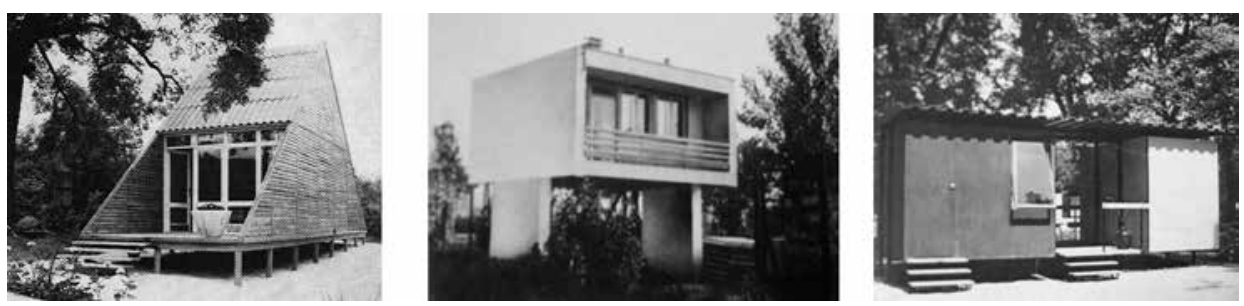

6. ábra. Típustervek a hatvanas-hetvenes évekből. Forrás: Callmeyer-Rojkó 1972

kus formálás jelent meg különösen azoknál az egyszerü, fal nélküli, sátortető formájú nyaralóknál, amelyek a későbbi, a nemzetközi szintéren népszerü „A-frame” típus hazai előfutárainak is tekinthetőek. Erre példa lehet Farkas Tibor Trió nevü nyaraló$\mathrm{ja}^{27}$ vagy Gulyás Zoltán ábrahámhegyi ikernyaralója ${ }^{28}$ (5. ábra). Preisich Gábor szigligeti épületének elemelt vasbeton tálcája acél lábakon áll, erre került rá a faszer-

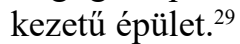

Az elöregyártott szerkezetek a hatvanas-hetvenes években terjedtek el a típustervek kidolgozásával párhuzamosan (6. ábra). A szerkezeti sokféleség nagyban hozzá-

${ }^{27}$ Farkas Tibor archívuma. A terveket a kutatás során a szerző feldolgozta.

${ }^{28}$ Gulyás 1968. 14.

${ }^{29}$ Callmeyer-Rojkó 1972. 
járult a zavaros településképi megjelenéshez, ezért Farkas Tibor foépítész kezdeményezésére felmerült egy üdülőhelyi szerkezetkészlet kialakítása, amit a Tüzép telepeken forgalmaztak volna. Néhány karakteres szerkezet, elsősorban a közismert, játékos szimbólumokat mutató kerítéselemek és ablakrácsok valóban elterjedtek a régióban. A típustervek fejlesztése során egyes tipizált nyaralókat teljes egészében karosszériaszerüen előregyártottak, erre példa a Vadász György és Callmeyer Ferenc által kidolgozott egység. ${ }^{30}$ Később, elsősorban az ERDÉRT forgalmazásában, a faszerkezetü, előregyártott elemekből összerakható házak is elterjedtek az ország valamennyi üdülöhelyén. ${ }^{31}$

A technológiák esetében még meg kell említenünk a saját kezü építést is. ${ }^{32} \mathrm{Ez}$ az építési mód kényszerből fakadt, de ugyanakkor szabadidős tevékenységként is előszeretettel gyakorolták a házépítők. Volt, hogy a már terv szerint megépült nyaralójukat építették tovább saját elgondolásuk és technikai lehetőségeik szerint, de egész épületeket, hajlékokat is összetákoltak ezzel a kezdetleges építési móddal. Az építészet perifériáját adó építésmódot a nyaralás vadon közelségét kereső, nomád létélményének megéléseként is felfoghatjuk, ahol az ember nemcsak a táji környezet, de az elemi építés valóságának megtapasztalásához is közel szeretne kerülni.

A nyaraló általános, „korszerü” szemléletű belsőépítészeti kialakításában Kaesz Gyula publikációja ma is iránymutató lehet. ${ }^{33} \mathrm{~A}$ kis alapterületủ hétvégi házba csak a legszükségesebb berendezési tárgyakat ajánlották elhelyezni. A praktikus kialakításhoz a modern szemléletet követő eltolható falak, összecsukható bútorok, a beépített szekrények és a hálószobákat felváltó minimális alapterületủ hálókamrák is hozzátartoztak. A falfülkébe helyezett és mennyezetig beépített szekrények magasan lévő polcain lehetett az utazás bőröndjeit tárolni. A bútorok esetében a színes, könnyü fém vagy puhafa vázas kialakításokat preferálta, föleg az összecsukható és az időjárásnak megfelelően a belső tér és a veranda közt szabadon áthelyezhető verziókat. A ,városi lakásokból kimustrált bútorokat” viszont nem tartotta alkalmasnak a nyaralók berendezésére, elsősorban méretüknél és reprezentatív jellegüknél fogva. A belső téri padlóburkolatoknál a városban megszokott parkettázást vagy puhafa padlót csak az alápincézett épületeknél alkalmaztak, a szellőzetlen épületekben inkább terazzo padlót építettek.

A nyaralóépítés konstrukciós szempontjait és lehetőségeit áttekintve összességében elmondható, hogy főként gazdaságossági megfontolások alapján az egyszerü, pragmatikus megoldásokat keresték, de ezek a tényezők a nyaralóépítészet esztétikai jellegét is jótékonyan formálták. A rendelkezésre álló helyi építőanyagok és techno-

\footnotetext{
${ }^{30}$ Uo.

${ }^{31}$ A cég kész épületeket fejlesztett ki, ezek közül a leginkább ismert épület a DO-30 típus, de az építőkészlet 1,6×2 méteres paneljeit szabadon kombinálva egyedi alaprajzi elrendezéseket is ki lehetett alakítani. Ezzel 43-63 $\mathrm{m}^{2}$ között változó alapterületü faházakat hozhattak létre a kreatív tulajdonosok. Internetes forrás az ERDÉRT faházak típusépületeinek müszaki paramétereiről. Lásd: „A balatoni telek kötelező kellékei a 70-es években." https://toretro.blog.hu/2018/07/31/a_balatoni_telek_kotelezo_kellekei_a_70-es_evekben (Utolsó megtekintés: 2019. 12. 29.)

${ }^{32}$ Bartha 2019.

${ }^{33}$ Kaesz 1944. 199-200; Kotsis 1934. 101-106.
} 
lógiák a tópart fokozatos modernizációja révén egyre jobban keveredtek a korszerü technológiákkal, sokszor vegyes konstrukciókat alakítva ki. A természetes építőanyagok ugyanakkor korszaktól függetlenül folyamatosan karakteres szerepet játszottak a nyaralóépítészetben.

\section{FORMÁLÁSI STRATÉGIÁK: KÜLSÖ HATÁSOK ÉS TÁJEGYSÉGI INSPIRÁCIÓK}

Az épületek formai kialakításában az előző fejezetekben már ismertetett, a szezonális életvitelből, gazdaságosságból és a táji, klimatikus adottságokból fakadó szempontok érvényesültek elsősorban. Ezek mint belső, regionális tényezők alapvetően formálták a nyaralóépítészetet és a jelenség korszakokon átívelő kohézióját is megadták. Mindezeken kívül ugyanakkor a korszakos építészeti formálási tendenciák, stílusirányzatok is éreztették hatásukat. A korszak nemzetközi nyaralóépítészeti mintáit bemutató kiadványokat, tematikus publikációit a hazai építészek is ismerhették, a külföldi üdülőhelyek nyaralóépítészete természetesen hatással volt a magyar nyaralóépítészetre is. ${ }^{34}$

A villaépítészet mint történeti előzmény leírásakor már utaltunk azokra a századfordulós hatásokra, melyek a nyaralóépítészet kibontakozásakor is még éreztették hatásukat. A történeti formák naiv átvételei, illetve a hegyvidéki üdülöterületeket megidéző „svájci villa” faszerkezetes kialakításai a korai nyaralóépületeken is megfigyelhetőek, természetesen a villákénál jóval kisebb léptékben. A léptékváltás révén azonban ezek a formajegyek ambivalens, de sok esetben szándékosan is humoros összképet alakítottak ki, föként azért, mert a korabeli kis összegből épülő nyaralókat képzetlen helyi kivitelezők tervezték és építették. ${ }^{35} \mathrm{~A}$ tópart fesztelen környezetében még ma is felfedezhetjük ezeket a tudatosan vagy tudattalanul az urbánus építészeti jegyeket ironikusan kiforgató formálási módokat, a kistornyos, sarokbástyás, rizalitos formajegyekből építkező, groteszk kialakításokat. A játékos formálás ugyanakkor kezdettől fogva az üdülőterületi építészet sajátos karakterét adja, és bár a későbbi korszakokban más és más eszközökkel, de folyamatosan jelen van a rekreációs célú építkezések eszköztárában.

Kotsis Iván a stíluspluralizmus problémáját veti fel a nyaralóépítkezések heterogén összképét látva. ${ }^{36} \mathrm{~A}$ húszas, harmincas években egymás mellett épültek fel a történeti hatásokat, a népi építészeti mintákat átértelmező és a „korszerü” modern építészetet követő alkotások. A két világháború között ugyanakkor nemcsak a tópartot, de általánosságban a hazai és nemzetközi építészetet is áthatotta a jelenség, egymás mellett épültek fel az eltérő felfogású épületek. A tópart egységes településképi kialakításához egy sajátos tervezési módszertant, ha tetszik regionális modellt

${ }^{34}$ A korai nemzetközi nyaralóépítészeti kiadványokra példa: nn 1907; Sörgel 1930; Carter 1937; Behne 1937.

${ }^{35}$ Körmendy 1931. 75-76.

${ }^{36}$ Kotsis 1931. 8-10. 
dolgozott ki, amellyel szándékai szerint egy autonóm üdülőterületi építészet alapjait rakhatja le. ${ }^{37}$ Olyan egyszerü megoldásokat keresett, amelyeket egyrészt könnyen és olcsón meg lehetett építeni, másrészt a helyi építőmesterek is könnyen követni tudtak. A formálásban számára meghatározó volt a klíma, az erős parti szél, ezért alacsonyhajlású, nagy ereszkiülésü tetőformát alakított ki, ami a modell meghatározó karakterévé vált. A szabadidő eltöltésének egyre könnyedebb felfogását követve a nyaralót tiszta térstruktúrával, nagy fedett-nyitott tereket adó verandákkal tervezte meg. A homlokzatok pasztellszínü, tagolatlan architektúráját zsalugáterekkel egészítette ki, ami az árnyékolás és ezáltal az épület belső mikroklímája, valamint a téli zárt időszakban a biztonság szempontjából is hatékony megoldás volt. A pragmatikus elvek karakteres és hamar széles körben elterjedő mintázatot eredményeztek, bár ahogy ezt Kotsis életrajzában beismeri, a tervezési elvek önkéntelenül is egy „olasz kerti ház alakját" adják ki. ${ }^{38}$ Ebben minden bizonnyal benne volt az építésznek az olasz építészet iránti erős vonzalma, ugyanakkor a tópart mediterrán üdülőhelyekkel párhuzamba állított karakterét a turisztika is kezdettől fogva tudatosan építette fel. Mindez mutatja, hogy az utazások és az olyan távoli tájak élményei, mint kezdetben az alpesi hegyvidék, később a mediterrán tengerpart építészete is beszürődtek a Balaton régió építéstörténetébe. Kotsis ugyanakkor egy olyan modellt dolgozott ki, amely a 20. század második felében is meghatározó kiindulási pontot adott a nyaralóépítészetben. ${ }^{39}$

A külhoni tájak inspirációja mellett a tájegységi vernakuláris kultúra is folyamatosan napirenden volt a 20. században. Bár Kotsis egy sajátos balatoni karaktert keresett, amiben a helyi építőanyagoknak is fontos szerepet szánt, tudatosan távol tartotta magától a népi építészet lakóházmegoldásait. Szerinte az üdülés életformája sokkal nyitottabb tereket kíván, mint amit egy parasztház térstruktúrája és szükös nyílásai biztosítani tudnak. A népi nyaraló problémája a 20. század egészén végighúzódik, sőt még napjainkban is aktuális. Toroczkai Wigand Ede 1923-as Hogyan épitsünk a Balaton-partján? címü kiadványában a Kós Károly és társai szemléletét követő irányzat jegyében tesz javaslatokat egy népies ihletésü nyaralóépítészetre. ${ }^{40}$ Szemlélete ugyanakkor nem tekinthető tájegységinek, sokkal inkább egy általános nemzeti építészet kialakítása foglalkoztatta, és ennek szellemében fogalmazta meg az üdülőhelyi vonatkozásokat. A tájegységi építészet iránti érdeklődés a harmincas években kezdett el formálódni, amikor Tóth Kálmán Nászay Miklóssal és PadányiGulyás Jenővel publikálta A Balaton-vidék népének épitészete címü könyvet. ${ }^{41}$ A kiadvány a Balatoni Intéző Bizottság támogatásával jelent meg, amely mint turisztikai szervezet élénk érdeklődést mutatott a helyi vernakuláris kultúra iránt. A népies nyaraló problémáját a BIB-ben szervező tevékenységet folytató Kotsis Iván is napirendre tüzte. Bár nem támogatta a törekvéseket, de egy esszépályázatot hirdetetett a

\footnotetext{
${ }^{37}$ Prakfalvi 2010. A tervezési modell részletes elemzését lásd: Wettstein 2013; Wettstein 2017.

${ }^{38}$ Perényi 2009.

${ }^{39}$ Farkas 1960. 15-26; Polónyi 2004.

${ }^{40}$ Toroczkai Wigand Ede: Hogyan épitsünk a Balaton-partján? Pátria Nyomda Táltos, Budapest 1923.

${ }^{41}$ Tóth-Nászay 1936.
} 
kérdéskör megvitatására. A kevés számú résztvevő miatt ugyanakkor a második lépésként ütemezett tervpályázatot már nem szervezte meg. A Balaton-felvidéket kutató építészcsoport a Magyar Ház Barátai néven később más tájegységek vizsgálatával is foglalkozott az országban, de Tóth Kálmán elkötelezett maradt a tóparttal és a második világháború után is aktívan részt vett a fejlesztésben. Nézetei tanítványára, Callmeyer Ferencre is hatással voltak, aki később a Típustervező Intézet munkatársaként a típusnyaralók kidolgozásában aktívan részt vett.

A vernakuláris kultúra inspirációja különösen az északi parti üdülőhelyeken mutatkozott erősnek. A déli part kvázi mesterséges apadási övén létrejött üdülőtelepekkel szemben itt a topografikus, táji adottságokból adódóan az ősközségek és az üdülöterületek közti határ gyakran elmosódott. A kiránduló turizmus desztinációi révén az üdülöhelyi építészetben is megjelentek a karakteres helyi, vernakuláris mintázatok. A helyi anyagokra és szerkezetekre a modern építészet is fogékonnyá vált, a hatvanas, hetvenes években számos nyaralót építettek modern szerkesztéssel, de a vernakuláris mintázatok inspirációjával. A korszak publikációi ugyanakkor Kotsisra támaszkodva csak a népi építészet „egyszerüségét” tartották követendőnek, a formamásolást elutasították. ${ }^{42}$ A korszak kiemelkedő tervezőegyéniségeinél a vernakuláris építésmódok inspirációja vélhetően az üdülőhelyi építészet természetessé-
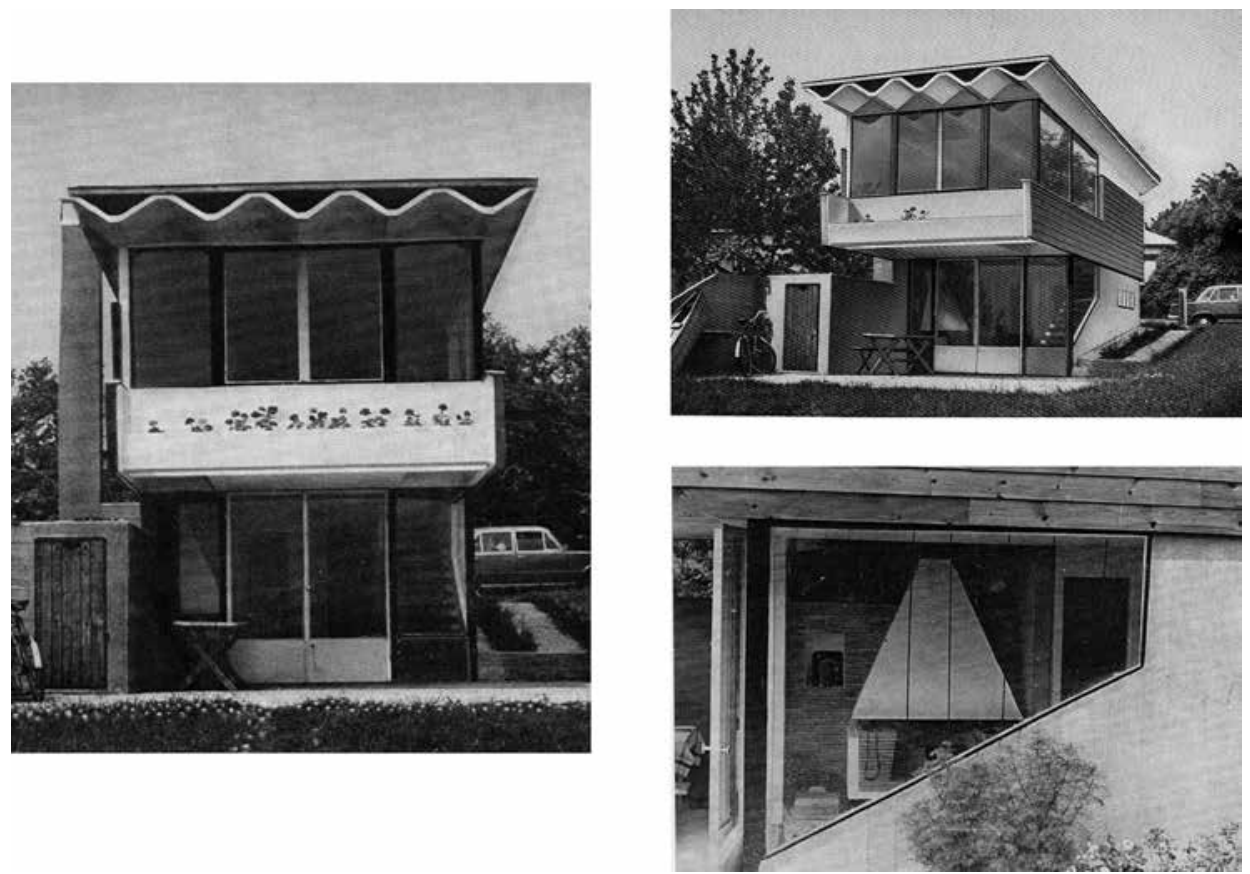

7. ábra. Farkas Tibor saját nyaralója Ábrahámhegyen. Forrás: Callmeyer-Rojkó 1972

${ }^{42}$ Bérczes et al. 1960. 15-26. 
géhez, a konstruálás alapelemeihez való vonzódásának tudható be inkább, mint a falusi kultúra iránti nosztalgiának. A népi mintázatok ugyanakkor egyre népszerübbé váltak a közízlésben, és sokszor a modern szerkesztési elveket is feladva építették meg a paraszti építészet másolatait. Ennek a tendenciának a nyolcvanas évek posztmodern hullámai adtak újabb lendületet, ami a turisztikai érdeklődést is egyre inkább a Balaton-felvidék vernakuláris kultúrája felé irányította. A nyaralóépítészet jelenségének lehatárolásánál ugyanakkor elsősorban a tópartra mint regionális szinten általánosítható üdülőhelyi jelenségre koncentrálunk. A Balaton-felvidék építészetében a falusias környezetben megjelenő üdülőházak egy különálló jelenségként értékelhetöek. Míg a modernizálódó tóparton az üdülőhelyi karaktert egy általános regionális szinten lehetett értelmezni, addig a falusias környezetben a lokális mikrokörnyezeti szint kontextusa értékelődött fel.

A történeti és tájegységi hatások mellett a nyaralóépítészet formálásában a modernitás vált meghatározó mozgatórugóvá. Ez igaz akkor is, ha a modernitás - főleg a kezdetekkor - nem feltétlen mutatkozott meg a „korszerü” modern építészet térnyerésében. Molnár József bevezetőben felvetett gondolatai épp erre a problémára utalnak. Vasvázas nyaralója már nagyon korán mutatja mindazt a szerkezeti és funkcionális invenciót, ami a későbbi korszakok nyaralóépítészetében is rendre megjelenik. Az urbánus környezetből kiszakadva fontos motívummá vált a felszabadult kísérle-

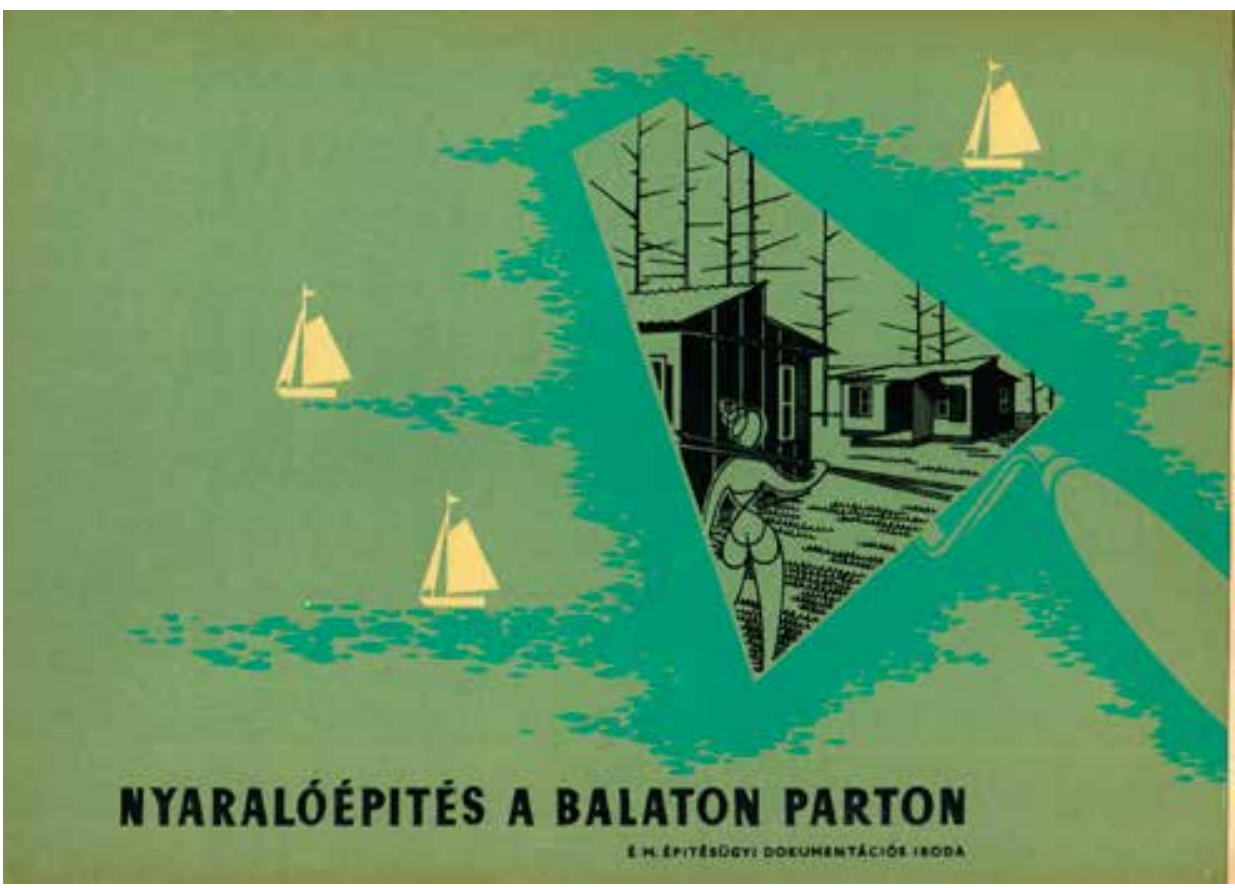

8. ábra. A Balaton-parti nyaralóépítési pályázat anyagát közzé tevő kiadvány, 1962. Forrás: nn 1962 
tezés. Ez sok esetben a játékos formálásban jelenik meg, ahogy azt más üdülőhelyi irányzatokban is megfigyelhettük. A modern felfogású hétvégi házaknál a vaskos hőszigeteléstől mentes szerkezetek könnyed kialakítása adott lehetőséget az innovatív formálásra. Farkas Tibor fóépítész karakteres lemezfedésủ saját nyaralóját gazdaságossági megfontolások alapján kísérletező szemlélettel alakította ki ${ }^{43}$ (7. ábra). A hatvanas, hetvenes évekre a modern tónusú nyaralóépítészet vált dominánssá, ugyanakkor a felfogásban mutatkozó különbségek nem eredményeztek egységes összképet. A korszak publikációi a „,pózna-lemez architektúra” egyszerüségét és könnyedségét hangsúlyozták, ugyanakkor az építésmódok sokféleségéből, a hagyományos falazott és a vázas technológiákból adódóan is eltérő karakterü épületeket építettek ${ }^{44} \mathrm{~A}$ korszak neves építészei is, bár mind a modern építészet szemléletét képviselték, más és más felfogásban dolgoztak. Ehhez a sokféle, ám a feladatból adódóan mégis koherens témakörhöz a hatvanas-hetvenes évekből a publikációk tükrében érdemes áttekinteni Csaba László és Cs. Juhász Sára nyaralóit, Szelle Kálmán akarattyai épületét, Oltai Pál földvári nyaralóját, Kleineisel János tihanyi pincegádorját. ${ }^{45}$ A modern építészet szikár, absztrakt formanyelve mellett folyamatosan jelen voltak azok az alternatív tendenciák, amelyek a helyi építőanyagokból, a konstruálás alapjaiból kívánták újradefiniálni az építészetet. A formálás szükségszerüen közel került a helyi építészet hagyományos alakzataihoz, ugyanakkor érdemes a jelenséget megkülönböztetni a későbbi, közvetlenebb vernakuláris inspirációt követő alkotásoktól. Erre a sajátos formálásra jó példák lehetnek a hatvanas évek elei nyaralótervpályázat alkotásai vagy a korábban már említett épületek, Farkas Tibor Trió, Gulyás Zoltán ábrahámhegyi vagy Preisich Gábor szigligeti nyaralója, ahol a szerkezeti kísérletezés és a játékos formálás egyszerre van jelen. Mindez a rekreáció fogalmának új dimenzióit nyitja meg, ahol az üdülőterület a szakmagyakorlás és a formálás számára is a felszabadult kísérletezés territóriumává válik ${ }^{46}$ (8. ábra).

\section{A MINTÁKTÓL A TÍPUSTERVEKIG - A TERVEZETTSÉG ELTÉRÖ FOKAI}

A nyaralóépítés jelenségében kezdettől fogva meghatározó volt a tömegesség, ami az építészeti tervezettség szintjeire és az építéshatósági kontroll stratégiáira is hatással volt. ${ }^{47} \mathrm{~A}$ tömegessé válás jelenségének fokozatait, azaz az egyre szélesebb társadalmi rétegek tóparti parcellához jutását, valamint az építész szakma pozícióit is jól

\footnotetext{
${ }^{43}$ Farkas Tibor hagyatéka. Valamint az épület publikációját lásd: Callmeyer-Rojkó 1972.

${ }^{44} \mathrm{~A}$,„pózna-lemez architektúra” fogalmi elemzését lásd: Wettstein $2018 \mathrm{a}$.

${ }^{45}$ Szelle 1969; Oltai 1962. 28; Cs. Juhász-Csaba 1964a 52-53; Cs. Juhász-Csaba 1964b 54-55; Cs. JuhászCsaba 1975; Kleineisel 1979. További nyaralóépületek: Callmeyer-Rojkó 1972.

${ }^{46}$ Wettstein 2016. A tervpályázatok közül különösen az 1960-as tervanyagban lelelhetőek fel ezek a szerkesztési elvek. Callmeyer 1960. 23-29; nn 1962.

${ }^{47} \mathrm{Az}$ építéshatósági munka harmincas évekbeli stratégiáiról lásd Wettstein 2017, a hatvanas évekbeli eszközeiről pedig lásd Wettstein 2018 b.
} 
mutatja a stratégiai eszközök átalakulási folyamata. Már Kotsis Iván nyaralótervezési modelljében, amelyet különböző kiadványokban és folyóiratokban széles körben publikált, fontos szempont volt, hogy azt a helyi, építésztervezői képzettséggel nem rendelkező kivitelező mesterek is következetesen adaptálni tudják. ${ }^{48}$ Az évközben egyetemi tanárként tevékenykedő építész nyári szabadidejében a környékbeli építőmestereket képezte Balatonbogláron. A Balatoni Intéző Bizottságban folytatott szervező tevékenységéhez számos korabeli építész csatlakozott, tervpályázatokon és tematikus kiadványokban publikálták mintaterveiket, kiállításokat szerveztek. ${ }^{49} \mathrm{Az}$ építéshatósági munkába is bekapcsolódtak az építészek, tanácsadással és korrekciókkal segítették az építészt foglalkoztatni nem tudó kis keresetü nyaralóépíttetőket. ${ }^{50}$ A két háború közti építkezések színvonalát és karakterét egyaránt meghatározták a könnyen adaptálható mintatervek. Mindez nagyban hozzájárult a korabeli üdülötelepek egységes arculatának kialakításához.

Míg a harmincas években még reális lehetőség volt az építészeti minőség színvonalának emelése csak irányadó, szabadon adaptálható mintatervek publikálásával, valamint a helyi kivitelezők szemléletformálásával, addig a háború után már egy strukturáltabb eszköztárra volt szükség mind a tervezés, mind a hatósági tevékenység terén. Farkas Tibor 1957 és 1968 között tevékenykedett föépítészként a tóparton, ebben az időben nagy hatékonysággal vezette a napi szintü ügymenetet, személyesen formálva a hatósági szereplők, ügyintézők és az építtetők szemléletét egyaránt. ${ }^{51}$ Munkáját kezdetben a MÉSZ önkéntes építészekből álló patronáló mozgalma is segítette, de az építészszakma települési szintü jelenlétét szorgalmazó szerveződés hamar kifulladt. Az 1960-as évek elejétől fogva egyre nőtt a belföldi lakosság által vásárolt nyaralótelkek száma. A nyaralótervezésből még mindig jelentősen részesedtek az építészeti képzettséggel nem rendelkező kivitelezők, valamint egyre problémásabbá vált a saját kezű építés jelensége. ${ }^{52}$ A hetvenes évektől jellemzősen a zártkerti területeken a szabályozás kijátszására szaporodtak el a házilagos eszközökkel megépített hétvégi házak. Ezeket az építményeket a legtöbb esetben építész bevonása nélkül építették meg. Bár a jelenséget gyakran a népi építészet tervező nélküli építőkultúrájával állítják tévesen párhuzamba, itt érdemes Polónyi Károly visszaemlékezésének a szerkezetválasztásnál már említett szakaszát ismét felidézni. A spontán építkezések esetében az építési helyzetek és technológiák sokfélesége miatt nem alakult ki olyan koherens építéskultúra, ami a megoldások minőségét jótékonyan befolyásolhatta volna.

Az építészeti minőség javítása érdekében több periódusban típustervgyüjteményeket adtak ki. A típustervek kidolgozásában a kor jeles építészei vettek részt, általában

\footnotetext{
${ }^{48}$ Prakfalvi 2010; Kotsis 1931. 8-10; Kotsis 1934. 102-106.

${ }^{49}$ Wettstein 2017.

${ }^{50}$ Héjj 1931. 77-80.

${ }^{51} \mathrm{~A}$ főépítészi tevékenységről és a regionális rendezési tervmüveletről lásd: Wettstein 2016; Wettstein 2018 b.

${ }^{52}$ A házilagos építés témaköréhez lásd: Bartha 2019.
} 

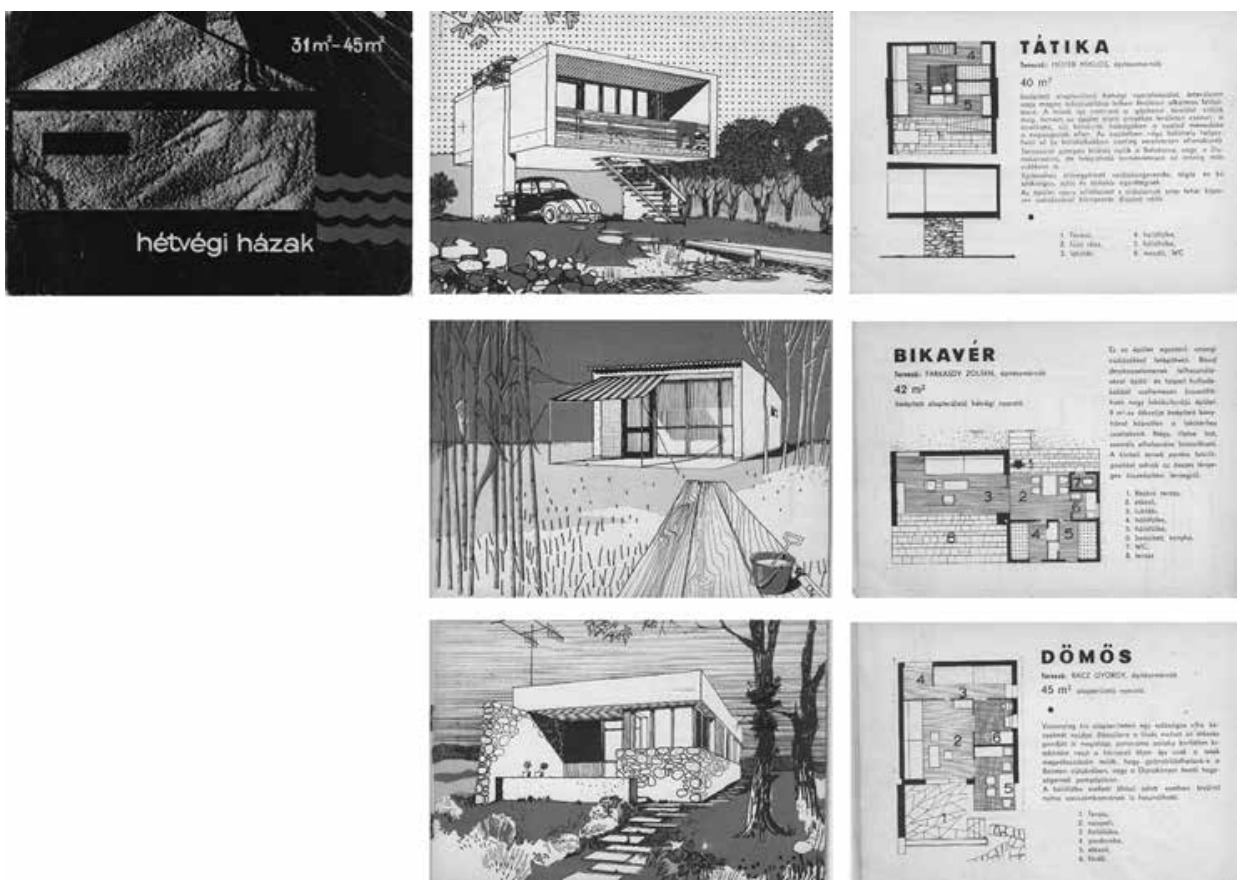

9. ábra. Nyaraló típustervek, 1965. Forrás: nn 1965

tervpályázati felhívás keretében. ${ }^{53} \mathrm{~A}$ szervezőmunkában meghatározó szereppel bírt a Tóth Kálmán révén már említett Callmeyer Ferenc is, aki a Típustervező Intézet munkatársaként koordinálta a terveket. Az első tervsorozatot 1960-ban kezdték el összeállítani, majd az 1965-ben kidolgozott tervgyüjteményben 52 tervet tettek közzé három méretkategóriában (9. ábra). A típustervek népszerüségét mutatja, hogy 1968-ban tovább kellett dolgozni az új igényeknek megfelelően. A kiadott tervek azonban rendkívül sokfélék voltak, a modern építészet korábban már felvázolt sokféle felfogását tükrözték ${ }^{54}$ (10. ábra). Voltak köztük a hagyományos építésmódokat, helyi építőanyagokat alkalmazó és az elöregyártott, iparosított technológiákat felhasználó típusok. Farkasdy Zoltán, aki szintén részt vett a tervek kidolgozásában, a típustervek sokféleségét látva fogalmazta meg egy rádióinterjúban, hogy az egységes településkép kialakításához ez a változatosság nem ad érdemi segítséget. ${ }^{55} \mathrm{~A}$ hetvenes évek elején Akali új parcellázású területén, a Levendulás telepen tettek kísérletet a típustervek egységes telepítésére Csorba Zoltán vezetésével. ${ }^{56}$ A népszerüsítő kiad-

${ }^{53}$ A nyaralóterv-pályázatokról és típustervekröl részletesebben lásd: Wettstein $2018 \mathrm{~b}$, valamint a korabeli publikációkat: Callmeyer 1960. 23-29; Schéry 1968. 9.

${ }^{54}$ A kiadványokat lásd: nn 1962; nn 1965 (kiadványsorozat a típusokat méretkategóriánként csoportosítva).

${ }^{55}$ Ferkai 2014. 159-161.

${ }^{56}$ Csorba 1977. 30. 
ványokban és gyüjteményekben közzétett típustervsorozatok tagjai játékos neveket viseltek, amelyek jellemzően a tájegységi karakterekre utaltak. A tervek kezdetben kifejezetten a Balaton-partra lettek kidolgozva, később azonban már általánosan alkalmazták őket a különböző üdülőterületeken. A Tátika vagy Csobánc típusterv éppúgy épült a Duna-kanyarban vagy a Duna mellett, ahogy a Búbánatvölgy vagy a Bikavér a Balatonnál. Mindez jól mutatja a regionális karakterjegyek elmosódását és az üdülőterületi építészet általános karakterjegyeinek előtérbe kerülését. A könnyen adaptálható, szabadon továbbformálható mintaterveket a 20. század második felében a jóval merevebb típustervek váltották fel. Ezek a típusok egyre inkább elszakadtak a tájegységi jellemzőktől és az üdülőterületi építészet általános tendenciáit erősítették.
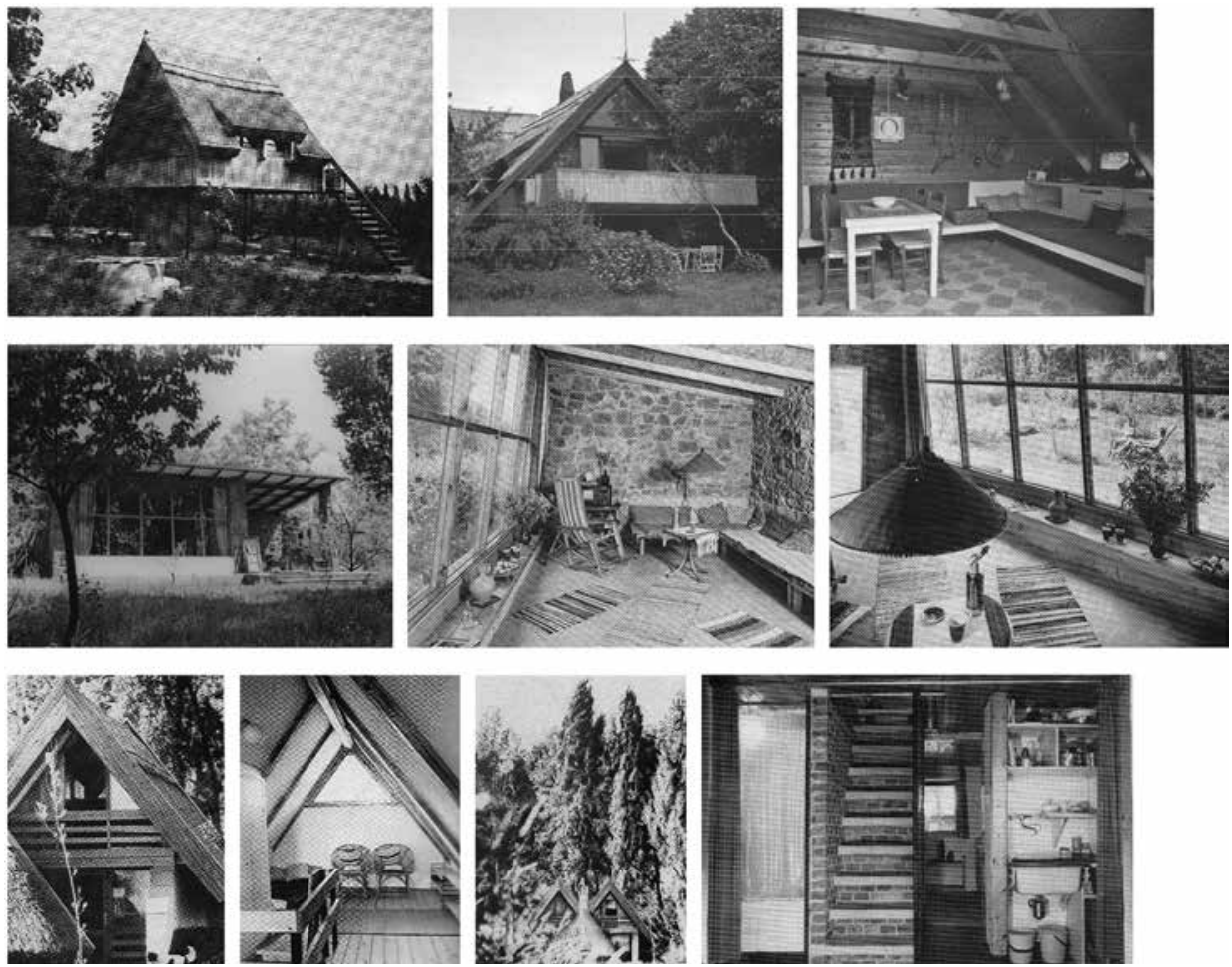

10. ábra. Preisich Gábor, Kismarty Lechner Kamill és Gulyás Zoltán nyaralói.

Forrás: Fehérvári-Prakfalvi 2009 (a kötetben publikált képek a Preisich család archívumából), Callmeyer-Rojkó 1972, valamint Farkas Tibor archívuma 


\section{KONKLÚZIÓ}

A Balaton-parti nyaralóépítészetben belső és külső hatások egyaránt keverednek, és bár kezdettől fogva fontos volt a táji környezethez, a helyi adottságokhoz való alkalmazkodás, az épületek meghatározó karakterét az üdülőhelyi életforma és a szezonális funkció alakította ki. Ėpp ezért a nyaraló regionális szintủ modelljét elsősorban nem formalizált stílusirányzatként, hanem építési feladatként foghatjuk fel, amelyre alternatív stratégiákat dolgoztak ki a korabeli szakemberek. A jelenséget mégis egységesnek tekinthetjük, erős kohéziót ad a szezonális életformához, a táji, klimatikus adottságokhoz és a szükös anyagi erősforrásokhoz alkalmazkodó szerkesztésmód. Visszatérö motívumként jelenik meg a kísérletező és játékos szemléletmód, ami szerkezeti innovációban, részletképzésben és anyaghasználatban egyaránt megmutatkozott. Napjainkban a jelenség kontúrjának elhalványodását épp ezen tényezők elvesztése okozza. Ahogy a nyaralóépítészet előzményét a térstruktúrájában összetettebb, szerkezeti-formai kialakításában nehézkesebb villaépítészet adta meg, úgy az életforma átalakulásával, a négyévszakos üdülőhelyi tartózkodás előtérbe helyezésével ismét a nagyobb léptékű tóparti villák építését helyezik előtérbe a magánépíttetők. A 20. századi hétvégi ház modelljét adó egyszerü kivitelü nyaralókat megújítani nem feltétlen gazdaságos, ezért egyre több esetben döntenek a bontás mellett. A kortárs építészet számára azonban irányadóak lehetnek a nyaralóépítészet számára felvázolt koncepciók, épp ezért a kutatás további lépései a koncepcionális irányzatok részletesebb feltárásai és a helyszíni esettanulmányok lesznek. A rekreáció a szakmagyakorlás számára is inspirációt jelentett, az építészek egyszerü alapelemekből, felszabadult formában konstruálhatták újra szakmafelfogásukról alkotott önképüket.

\section{IRODALOM}

Antal 1931

Bartha 2019

Behne 1937

Bérczes et al. 1960

Bősze 1989

Callmeyer 1960

Callmeyer 1965
Antal Dezső (szerk.): Balaton. Tér és Forma kiadása, Budapest 1931.

Bartha András: Saját kezü épités. Épitöanyagok második élete a Balaton körül. DLA Doktori disszertáció. BME Építészmérnöki Kar Építőmüvészeti Doktori Iskola, 2019.

Adolf Behne: Wochenende - und was man dazu braucht. Orell Füssli, Zürich 1931.

Bérczes István - Farkas Tibor - Kisléghy Nagy István - Polónyi Károly: Beszámoló a Balatonkörnyék fejlesztéséről. Magyar Épitömüvészet 9 (1960) 6. 15-26.

Bősze Sándor: A Dél-Balatoni fürdőegyesületek történetéből (1890-1944). In: Somogy megye múltjából - Levéltári évkönyv 20. Szerk. Kanyar József. Kaposvár 1989. 211-252.

Callmeyer Ferenc: Hétvégi ház pályázat. Magyar Épitőmüvészet 9 (1960) 1. 23-29.

Callmeyer Ferenc: Hétvégi házak, nyaralók. Magyar Épitőmüvészet 14 (1965) 6. 32-37. 
Callmeyer-Rojkó 1972

Carter 1937

Cs. Juhász-Csaba 1964a

Cs. Juhász-Csaba 1964b

Cs. Juhász-Csaba 1975

Csorba 1977

Fabiny 1935

Farkas 1960

Fehérvári-Prakfalvi 2009

Ferkai 2014

Firnigl 2012

Gulyás 1968

Héjj 1931

Kaesz 1944

Kleineisel 1979

Komor 1931

Kotsis 1931

Kotsis 1934

Kotsis 1946

Körmendy 1931

Laposa 1979

Meggyesi 2005

Molnár 1931

Möller 1944
Callmeyer Ferenc - Rojkó Ervin: Hétvégi házak-nyaralók. Müszaki Könyvkiadó, Budapest 1972.

Ella Carter (ed.): Seaside houses and bungalows. Country Life, London 1937.

Cs. Juhász Sára - Csaba László: Nyaraló Balatonakarattya. Magyar Épitömüvészet 13 (1964) 6. 52-53.

Cs. Juhász Sára - Csaba László: Nyaraló Balatongyörök. Magyar Épitömüvészet 13 (1964) 6. 54-55.

Cs. Juhász Sára - Csaba László: Nyaraló Tihanyban. Magyar Épitőmüvészet 24 (1975) 2. 44-45.

Csorba Zoltán: Egy kísérleti nyaralóteleppel kapcsolatos tanulságok. Városépités 14 (1977) 4. 30.

Fabiny Tihamér: Építkezés a Balaton mentén. Tér és Forma 8 (1935) 3. 65-66.

Farkas Tibor: Beszámoló a Balaton-környék fejlesztéséröl. Magyar Épitömüvészet 9 (1960) 15-26.

Fehérvári Zoltán - Prakfalvi Endre: Preisich Gábor. Épitészeti, városépitészeti pályafutásom története. Lapis Angularis VII. Források a Magyar Építészeti Múzeum gyűjteményéből. Magyar Építészeti Múzeum, Budapest 2009.

Ferkai András: Farkasdy Zoltán épitészete. HAP, Budapest 2014.

Firnigl Anett: Római kori villák történeti környezetének vizsgálata a Balatonfelvidéken. Doktori értekezés. BCE-TK, Budapest 2012.

Gulyás Zoltán: Ikernyaraló, Ábrahámhegy. Magyar Épitömüvészet 17 (1968) 4. 14.

Héjj Gyula: A balatoni építkezések hatósági felügyelete. In: Balaton. Szerk. Antal Dezső. Tér és Forma, Budapest 1931. 77-80.

Kaesz Gyula: Tanácsok nyaralók berendezéséhez. Magyar Épitömüvészet 43 (1944) 8. 199-200.

Kleineisel János: Pincegádor Tihanyban, Cserhegy. Magyar Építőmüvészet 28 (1979) 5. 36-37.

Komor János: Hogyan építünk és hogyan kellene építenünk a Balatonparton? Tér és Forma 4 (1931) 2. 41-66.

Kotsis, Iván: Müvészet a balatoni építkezésekben. In: Balaton. Szerk. Antal Dezső. Tér és Forma, Budapest 1931. 8-10.

Kotsis Iván: A nyaralók építéséről. Magyar Mérnök és Épitész Egylet Közlönye 68 (1934) 17-18. 102-106.

Kotsis Iván: Épületek és tervek. Pósa Károly Könyvkereskedő Kiadása, Budapest 1946.

Körmendy Nándor: A balatonmelléki építkezések tervezési és vállalkozási munkakörének rögzítése. In: Balaton. Szerk. Antal Dezső. Tér és Forma, Budapest 1931. 75-76.

Laposa József: Zártkertek a Balaton körül. Területrendezés 2 (1979) 1. 86-95.

Meggyesi Tamás: A 20. század urbanisztikájának útvesztőii. Terc, Budapest 2005.

Molnár József: Vasvázas hétvégi házak a Balaton Lidón (Siófok). Tér és Forma 4 (1931) 9. 297-298.

Möller Károly: Szerkezeti szempontok a balatoni nyaralóépítkezéseknél. Magyar Épitőmüvészet 43 (1944) 8. 200. 
Nemes 1934

Nemes 1935

Nemes 1941

Németh 2016

nn 1907

nn 1962

nn 1965

Oltai 1962

Ormos 1963

Perényi 2009

Polónyi 2004

Prakfalvi 2010

Schéry 1968

Schulek 1934

Sörgel 1930

Szabó 1968

Szabó 1972

Széll 1934

Szelle 1969

Tóth-Nászay 1936

Wettstein 2012

Wettstein 2013

Wettstein 2016
Nemes Árpád: Irányelvek a balatoni építkezésekhez. Magyar Mérnök és Épitész Egylet Közlönye 68 (1934) 17-18. 111.

Nemes Árpád: Hogyan építsünk a Balatonpartján? Tér és Forma 8 (1935) 3. 69-78.

Nemes Árpád: Balatonvidék rendezési és építészeti kérdései. Magyar Épitömüvészet 40 (1941) 6. 159-162.

Németh Szandra: A Balaton mindenkié? A szocialista időszakbeli nyaralóépítések egyéni motivációinak vizsgálata. Korall (2016) 64. 137-156.

nn: Sommer- und Ferienhäuser aus dem Wettbewerb der Woche. Die Woche 1907.

nn: Nyaralóépités a Balaton-parton. ÉM Dokumentációs Iroda, Budapest 1962.

nn: É. M. Típustervezö Intézet: Hétvégi házak, nyaraló épületek. É. M. Építésügyi Dokumentációs Iroda, Budapest 1965.

Oltai Pál: Hétvégi ház Balatonföldvár. Magyar Épitömüvészet 11 (1962) 2. 28 .

Ormos Imre: A szabad táj mint a nagyvárosok lakóinak üdülőterülete. In: A kertészeti és szölészeti föiskola évkönyve XXVII. évf. Mezőgazdasági Kiadó, Budapest 1963. 189-208.

Perényi Tamás (szerk.): Kotsis Iván: Írások, házak, tanítványok. BME Lakóépülettervezési Tanszék, Budapest 2009.

Polónyi Károly: Építész-településtervezö a perifériákon - Polónyi Károly retrospektív naplója. Terc Kiadó, Budapest 2004.

Prakfalvi Endre (szerk.): Kotsis Iván: Életrajzom. HAP Tervezőiroda Kft. és a Magyar Építészeti Múzeum közös kiadása, Budapest 2010.

Schéry Gábor: Nyaralóépületek tervpályázata. Magyar Építőmüvészet 17 (1968) 4. 9.

Schulek János: Hétvégi házak építése. Bevezetés. Magyar Mérnök és Épitész Egylet Közlönye 68 (1934) 17-18. 101.

Herman Sörgel: Das Haus fürs Wochenende. Gebhardt Verlag, Leipzig 1930.

Szabó Iván: „Baricska” társas üdülőtelep, Balatonfüred. Magyar Épitömüvészet 17 (1968) 4. 14.

Szabó Iván: Neptun társasüdülő. Magyar Épitőmüvészet 21 (1972) 3. 23. Széll László: Hétvégi és kisebb igényű nyaralóházak felépítésére leginkább alkalmas szerkezetek. Magyar Mérnök és Épitész Egylet Közlönye 68 (1934) 17-18. 112-115.

Szelle Kálmán: Nyaraló, Balatonakarattya. Magyar Épitőmüvészet 18 (1969) 3. 30.

Tóth Kálmán - Nászay Miklós: A Balaton vidék népének épitészete. Balatoni Intéző Bizottság, Budapest 1936.

Wettstein Domonkos: Fürdőtelepek és rekreációs célú együttesek rehabilitációja a Balaton-parton egy esettanulmány tükrében. In: A környezettudatos települések felé. III. Települési Környezet Konferencia. Szerk.: Fazekas István - Szabó Valéria. Meridián Alapítvány, Debrecen 2012. 228-233.

Wettstein Domonkos: Építészet, identitás, Balaton. Regionális stratégiakeresés a harmincas és a hatvanas évek építészetében. Utóirat: A Régi-Új Magyar Épitömüvészet Melléklete 13 (2013) 72. 23-28.

Wettstein Domonkos: The Balaton region as an experimental territory. Positions of architecture in the emergence of regional planning for recreation in Hungary. Épités - Épitészettudomány 44 (2016) 1-2. 129-177. 
Wettstein 2017

Wettstein 2018a

Wettstein 2018b
Wettstein Domonkos: Regionális törekvések a Balaton-parti üdülöterületek építéstörténetében a két világháború között. Épités - Épitészettudomány 45 (2017) 1-2. 139-171.

Wettstein Domonkos: Regionális stratégiaalkotás a Balaton-part rekreációs célú épitészetében (1929-1979). Doktori disszertáció. BME Építészmérnöki Kar Csonka Pál Doktori Iskola, 2018.

Wettstein Domonkos: A „nagy számok” apró építészete - a magánépítkezések problémái a hatvanas évek Balaton-partján. Comitatus: Önkormányzati Szemle különszám (2018) 37-46.

\title{
HOLIDAY HOME ARCHITECTURE ON THE SHORE OF LAKE BALATON IN THE MIRROR OF $20^{\mathrm{TH}}-\mathrm{CENTURY} \mathrm{LIFESTYLES}$ OF RECREATION
}

\begin{abstract}
Summary
The Lake Balaton holiday home has become a characteristic building type of the twentieth century in Hungary, but due to the small scale of the task it has become less prominent in the literature. The aim of the study is to analyse the Balaton shore as a regional phenomenon. The paper seeks to answer how the characteristics of the emerging building type of the $20^{\text {th }}$ century can be defined. How do changes in architectural features correlate with resort lifestyle changes? The source of the analysis on the conceptual level is the publications of the $20^{\text {th }}$-century holiday architecture. The method of processing examines the phenomenon of the cottage on the level of intellectual history as conceptual answers to the regional model, and presents the built examples to illustrate the concepts. The study looks at the characteristics of holiday architecture in isolation from historical villa architecture and highlights the characteristics of $20^{\text {th }}$-century resort lifestyles, structural considerations, and design strategies. The study concludes that the characteristics of holiday architecture are strongly related to the seasonal lifestyle, so the change in the lifestyle of the lakeside, the four-season use leads to a change in the forms of housing that fade the lakeside features of the former simple, nature-friendly holiday design. The study points out the effects of formation trends beyond the region and emphasizes that although the concept of the Balaton shore has been developed to suit local conditions, the features of the building type have been linked to the general characteristics of recreation. As a result, patterns created in the region have appeared in other resorts, dissolving the regional characters.
\end{abstract}

Keywords: holiday home, weekend house, Lake Balaton, regional planning, modern architecture, recreation

Open Access nyilatkozat: A cikk a Creative Commons Attribution 4.0 International License (https://creativecommons.org/licenses/by/4.0) feltételei szerint publikált Open Access közlemény, melynek szellemében a cikk bármilyen médiumban szabadon felhasználható, megosztható és újraközölhető, feltéve, hogy az eredeti szerző és a közlés helye, illetve a CC License linkje és az esetlegesen végrehajtott módosítások feltüntetésre kerülnek. (SID_1)

Beérkezett: 2020. január 10. Elfogadva: 2020. január 11.

Online First megjelenése: 2020. február 17. 